\title{
Vascularization Strategies for Tissue Engineering
}

\author{
Michael Lovett, Ph.D., ${ }^{1}$ Kyongbum Lee, Ph.D., ${ }^{2}$ Aurelie Edwards, Ph.D., ${ }^{2}$ and David L. Kaplan, Ph.D., ${ }^{1,2}$
}

Tissue engineering is currently limited by the inability to adequately vascularize tissues in vitro or in vivo. Issues of nutrient perfusion and mass transport limitations, especially oxygen diffusion, restrict construct development to smaller than clinically relevant dimensions and limit the ability for in vivo integration. There is much interest in the field as researchers have undertaken a variety of approaches to vascularization, including material functionalization, scaffold design, microfabrication, bioreactor development, endothelial cell seeding, modular assembly, and in vivo systems. Efforts to model and measure oxygen diffusion and consumption within these engineered tissues have sought to quantitatively assess and improve these design strategies. This review assesses the current state of the field by outlining the prevailing approaches taken toward producing vascularized tissues and highlighting their strengths and weaknesses.

\section{Introduction}

A RGUABLY THE BIGGEST CHALLENGE in the field of tissue engineering remains mass transfer limitations. This is the limiting factor in the size of any tissue construct grown in vitro, as well as the subsequent integration of these constructs in vivo, regardless of the tissue-specific goal. Within the body, most cells are found no more than $100-200 \mu \mathrm{m}$ from the nearest capillary, with this spacing providing sufficient diffusion of oxygen, nutrients, and waste products to support and maintain viable tissue. ${ }^{1}$ Likewise, when tissues grown in the laboratory are implanted into the body, this diffusion limitation allows only cells within 100-200 $\mu \mathrm{m}$ from the nearest capillary to survive. ${ }^{2}$ Thus, it is critical that a tissue be prevascularized before implantation with proper consideration given to the cell and tissue type, oxygen and nutrient diffusion rates, overall construct size, and integration with host vasculature. In the laboratory, limited diffusion of oxygen is the primary reason that construction of tissues greater than a few hundred microns in thickness is currently not practicable. As most constructs rely on diffusion for oxygen transport into the tissue, gradients are often produced within the constructs, resulting in spatial variations in cell number, viability, and phenotype stemming from differences in oxygen and nutrient concentration.

Current approaches to address this pervasive problem in the field generally fall into six major categories: (a) scaffold functionalization, (b) cell-based techniques, (c) bioreactor designs, (d) microelectromechanical systems (MEMS)-related approaches, (e) modular assembly, and (f) in vivo systems (Fig. 1). Scaffolds may be functionalized through different angiogenic factor-loading techniques or through increased porosity or channeling of scaffolds to form perfusion elements. Examples include vascular endothelial growth factor (VEGF), platelet-derived growth factor (PDGF), and heparinimpregnated scaffolds or laser-cored porous scaffolds, ${ }^{3-5}$ with these systems typically aimed at encouraging angiogenesis in vivo and reducing oxygen and nutrient gradient formation. Bioreactor systems are designed and employed in the growth of tissues in vitro to facilitate improved nutrient and oxygen transport, with examples including perfusion systems, rotating systems, and spinner flasks. These systems result in improved transport and can result in enhanced rate and quality of tissues generated in vitro. The use of MEMS and microfluidic technologies to recapitulate the branching network of the microvasculature is an alternative approach being pursued in many labs, with systems generally formed from nondegradable materials such as silicone or polydimethyl siloxane (PDMS), though more recent approaches have focused on developing degradable systems. Cell-based techniques have involved cocultures of endothelial cells with the cell type of interest as well as prevascularization both in vivo and in vitro. These techniques can provide functional vasculature throughout the construct, though issues of cell culture time and functional anastomosis with host vessels remain a concern. Modular assembly is a newer approach that combines minimal functional units (e.g., an endothelial cellcoated hydrogel or a microtube-hydrogel composite system) to build up a larger vascular network. Finally, in vivo systems such as polysurgery techniques or arteriovenous (AV) loops utilize the natural angiogenic potential of an organism to vascularize engineered tissues within the body.

In each case, there are two critical points to producing a viable construct, the ability to measure and model the oxygen

Departments of ${ }^{1}$ Biomedical Engineering and ${ }^{2}$ Chemical and Biological Engineering, Tufts University, Medford, Massachusetts. 


\section{A}

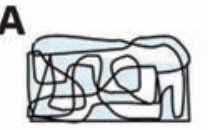

:
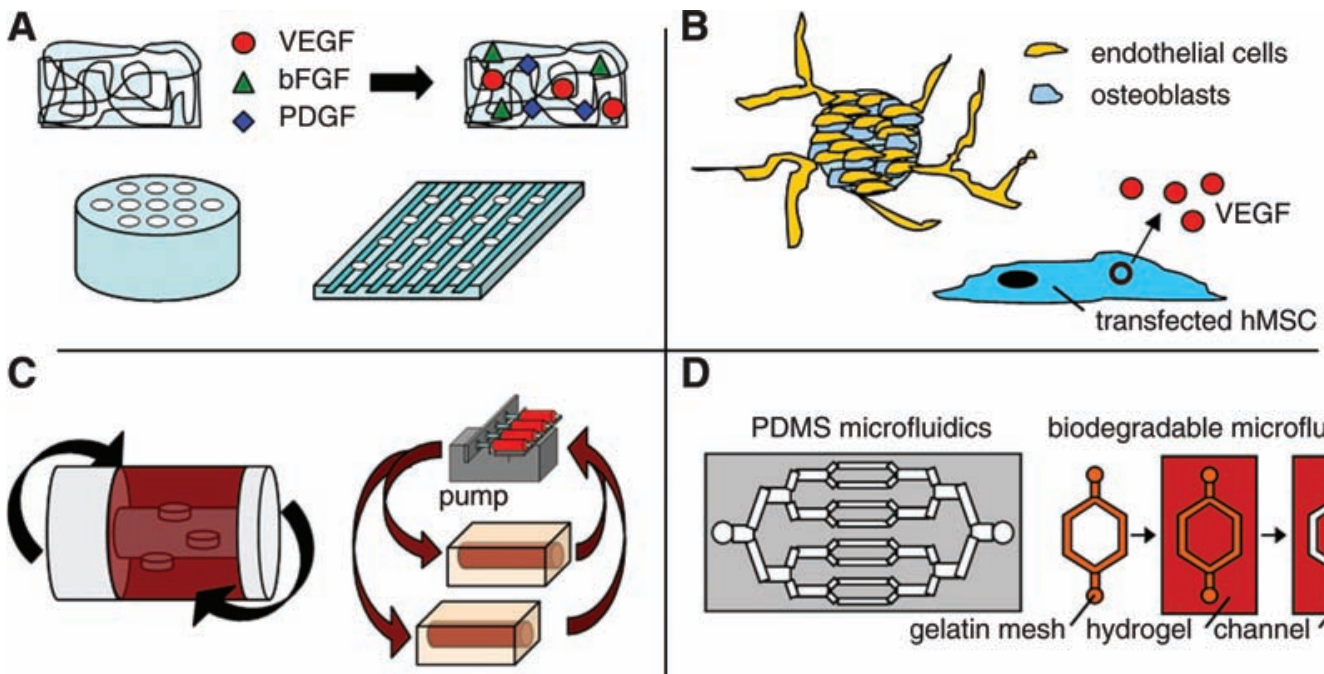

E

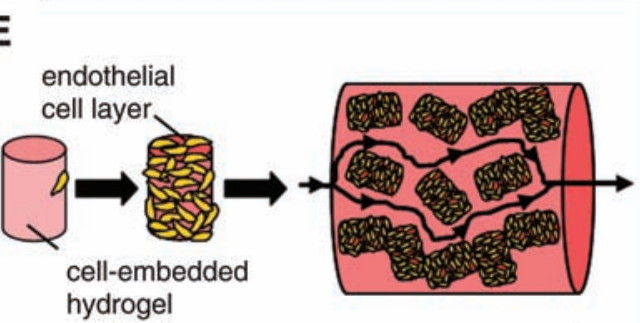

\section{$\mathbf{F}$}
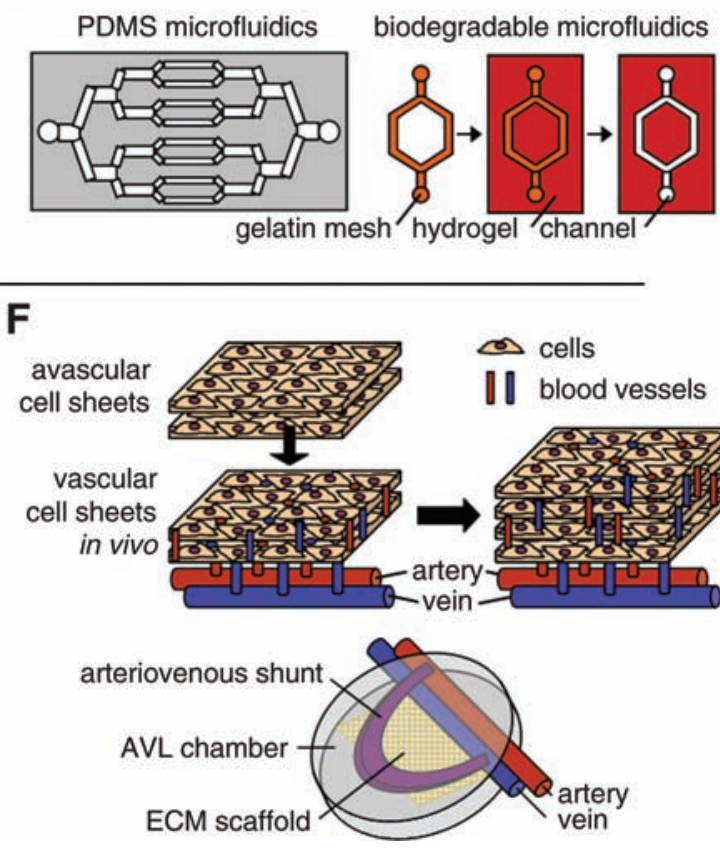

FIG. 1. Schematic diagrams of different vascularization approaches. (A) Scaffold functionalization. Tissue engineering scaffolds may be loaded or chemically coupled with angiogenic factors, including vascular endothelial growth factor (VEGF), basic fibroblast growth factor (bFGF), and platelet-derived growth factor (PDGF), among others. They may also be designed and engineered to have microchannels or porous microgrooves to improve oxygen/nutrient perfusion or vascular cell alignment, respectively. (B) Cell-based techniques. Multi-cellular spheroid cultures are used to generate capillary-like sprouts when embedded within a biological matrix. Other cell-based techniques include the use of transfected cells to secrete angiogenic factors within a scaffold to induce blood vessel formation. (C) Bioreactor designs. Rotating bioreactors or perfusion bioreactors are used to overcome issues of mass transport in culture, with perfusion bioreactors being particularly useful for forming functional arteries in vitro. (D) Microelectromechanical systems-related approaches. Microfluidic systems are used to form a vascular tree-like organization within a synthetic or biodegradable polymer. These systems can subsequently be seeded with endothelial cells to form a rudimentary vasculature. (E) Modular assembly. Microtissues composed of cell-embedded hydrogels covered with a confluent endothelial cell layer have been combined together to form a macrotissue under perfusion, with the endothelial cell layer acting as an antithrombogenic surface. Vessel-embedded hydrogel systems are used to quantitatively measure nutrient and oxygen permeability before translating that knowledge into forming critically sized multi-vascular modules with one inlet and outlet. (F) In vivo systems. Confluent cell sheets are stacked and vascularized upon implantation adjacent to arteries and veins before building tissue thickness through the addition of more acellular layers for vascularization. Arteriovenous (AV) loops are used to vascularize tissues in vivo within a chamber housing the arteriovenous loop with or without an extracellular matrix (ECM) scaffold or cells. Color images available online at www liebertonline.com/ten.

tensions throughout the engineered tissue as well as points of functional anastomosis to connect graft-originated prevascular structure with host blood vessels. For quantitative measurement of oxygen, consideration of the flow rates through the scaffold, diffusion coefficients within each tissue region, and oxygen consumption rates of each specific cell type dictates the overall model of oxygen distribution within the construct. While each scaffold requires the use of modeling equations specific to its geometric and biological conditions, simple use of Fick's law of diffusion, Michaelis-
Menten kinetics, Navier-Stokes equations, and Darcy's law for flow through porous medium often provide basic understanding of the system. Further direct measurement of oxygen concentrations within the scaffold using oxygen probes or oxygen-sensitive dyes allows these models to be quantitatively evaluated, ultimately providing a more thorough understanding of the vascularization process and the oxygen requirements for a given tissue type. For establishing a connection between prevascularized tissues and host vasculature, consideration for the size of connection, required 
flow rates, and ease of integration are critical to the ultimate viability of the implanted tissue. If a tissue-engineered construct is implanted without connection to host blood vessels, oxygen and nutrient supply becomes a diffusion-limited process, resulting in loss of cell viability at the core of the engineered tissue as dictated by its oxygen and nutrient requirements. By designing a prevascularized tissue with connections to host vasculature, the cells within the construct are immediately supplied with the required nutrients from the moment of implantation. Thus, the combination of quantitative measurement and modeling of oxygen and nutrient requirements to account for proper spacing of vessels with connection points for anastomosis to provide immediate functionality in vivo serve as the fundamental guide points for the design of vascularized tissues.

In this review, we present the current state of the art for each vascularization technique and the work being performed using each strategy. With particular focus on translating engineered tissues from in vitro to in vivo studies, the mechanisms of vascularization, quantitative measurements of nutrient and oxygen diffusion, and potential for functional anastomosis with host vasculature will be highlighted for each technique. Further, quantitative methods to model and measure oxygen diffusion and consumption within a tissue will be presented. All together, this review serves to outline the fundamental strategies needed to produce fully vascularized tissues in vitro and in vivo, with focus on controlling oxygen distribution and vascular integration.

\section{Scaffold Functionalization}

\section{Growth factor delivery}

One of the classical approaches to producing larger tissues has been to decorate or supplement scaffolds, either natural or synthetic, with pro-angiogenic factors such as VEGF, basic fibroblast growth factor (bFGF), or PDGF (Table 1). ${ }^{6-10}$ This decoration mimics the in vivo condition where these factors are associated with the extracellular matrix (ECM) to stabilize conformation and protect from proteolytic digestion or nonspecific release. ${ }^{3}$ Single-factor release systems have focused on a broad array of different growth factors, scaffold materials, and means of entrapment. The most basic loading technique is to simply coat or load the scaffold with the growth factor of interest. Loading within a natural biopolymer scaffold is inviting, as they are typically processed in aqueous conditions, are well-characterized, and may be comprised of native ECM molecules. Collagen, in particular, has shown promise with PDGF and has been formed into scaffolds that enhance capillary formation in a dermal wound healing model. ${ }^{11,12}$ Alginate scaffolds loaded with VEGF have also been shown to promote vascularization. ${ }^{13}$ Synthetic scaffolds such as poly(lactic-co-glycolic acid) (PLGA) mixed with VEGF have also supported increased vascularization. $^{14,15}$

Beyond these basic scaffold-loading approaches, protein modification techniques have been applied to scaffolds by forming binding domains for angiogenic factors via fusion proteins or coupling using 1-ethyl-3-(3-dimethylaminopropyl)-carbodiimide (EDC) and $\mathrm{N}$-hydroxysuccinimide (NHS) chemistry. Fusion proteins composed of hepatocyte growth factor and a collagen-binding domain have been used to facilitate loading of hepatocyte growth factor, subsequently promoting capillary formation in gel culture in vitro as well as blood vessel growth in vivo. ${ }^{16}$ Likewise, fusion proteins of bFGF and fibrin-binding peptide Kringle1, or PDGF and collagen-binding domains, have been utilized to couple bFGF or PDGF to fibrin or collagen gels, respectively, with each technique producing scaffolds that promoted neovascularization in vivo in rat models. ${ }^{17,18}$ As an alternative to modifying the growth factor of interest, scaffolds can

Table 1. Summary of Currently Used Vascular Growth/Signaling Factors

\begin{tabular}{|c|c|c|c|c|}
\hline & Growth/signaling factor & Function & Critical issues & References \\
\hline \multirow[t]{5}{*}{$\begin{array}{l}\text { Time course } \\
\text { of delivery }\end{array}$} & $\begin{array}{l}\text { Vascular endothelial } \\
\text { growth factor }\end{array}$ & $\begin{array}{l}\text { Most important family of cytokines in } \\
\text { neovascularization; initiator of } \\
\text { endothelial capillary formation; }\end{array}$ & $\begin{array}{l}\text { Rapidly degraded due to } \\
\text { short half-life; excessive } \\
\text { amounts cause vascular } \\
\text { leakage }\end{array}$ & $3,6,7,14$ \\
\hline & $\begin{array}{l}\text { Basic fibroblast } \\
\text { growth factor }\end{array}$ & $\begin{array}{l}\text { Heparin-binding protein; induces } \\
\text { proliferation of ECs, SMCs; } \\
\text { initiator of endothelial capillary } \\
\text { formation }\end{array}$ & $\begin{array}{l}\text { Rapidly diffuses, requires } \\
\text { controlled release; } \\
\text { mitogen for wide } \\
\text { variety of cell types }\end{array}$ & $3,18,26$ \\
\hline & $\begin{array}{l}\text { Hepatocyte } \\
\text { growth factor }\end{array}$ & $\begin{array}{l}\text { Mitogen of hepatocytes and other } \\
\text { various cell types; stimulates } \\
\text { growth of ECs but not SMCs }\end{array}$ & $\begin{array}{l}\text { Short half-life, rapid } \\
\text { diffusion; large } \\
\text { amounts of protein } \\
\text { required for response }\end{array}$ & 17 \\
\hline & $\begin{array}{l}\text { Platelet-derived } \\
\text { growth factor }\end{array}$ & $\begin{array}{l}\text { Mitogen for connective tissue } \\
\text { cells, released from platelets; } \\
\text { recruits SMCs to endothelial } \\
\text { linings; promotes vessel maturation }\end{array}$ & $\begin{array}{l}\text { High levels result in } \\
\text { vessel destabilization; } \\
\text { increased activity } \\
\text { linked with several } \\
\text { diseases }\end{array}$ & $9,13,25$ \\
\hline & Angiopoietin-1 & $\begin{array}{l}\text { Plays key regulatory role in } \\
\text { regulating vessel homeostasis; } \\
\text { promotes EC migration, stabilization } \\
\text { of newly formed capillaries }\end{array}$ & $\begin{array}{l}\text { Overexpression induces } \\
\text { endothelial hyperplasia } \\
\text { and reduced vessel } \\
\text { leakage }\end{array}$ & $3,8,10,11$ \\
\hline
\end{tabular}

SMCs, smooth muscle cells; ECs, endothelial cells. 
be modified with binding sites. As an example, modification of collagen matrices by covalently incorporating heparin using EDC-NHS chemistry allowed for enhanced immobilization of VEGF via its heparin-binding domain, and the combination of these two angiogenic factors induced increased endothelial cell growth and tube formation. ${ }^{19-21} \mathrm{Be}-$ yond these methods, others have directly coupled growth factors to scaffolds including VEGF to collagen scaffolds or generated a gene-activated matrix by coating plasmid coding for human VEGF onto collagen sponges. ${ }^{22,23}$

While success has been realized with these different types of bulk-loading and surface-coupling approaches, there remain problems with restricting the delivery of these proangiogenic factors to the region of need as well as controlling the temporal release profile. ${ }^{3}$ Thus, drug-loaded microspheres incorporated into scaffolds have been explored, either with or without bulk or surface loading as described above. As an example, the release kinetics of two growth factors, VEGF and PDGF, were studied together in a polymer system (PLGA) where VEGF was mixed with the PLGA particles used to produce the scaffold and PDGF was preencapsulated into microspheres before forming the scaffold. This procedure deposited the VEGF largely on the surface of the polymer where it was rapidly released. The polymerencapsulated PDGF, however, was more evenly distributed throughout the scaffold and was released more slowly through bulk degradation. ${ }^{24}$ As a result, upon implantation in vivo, the mechanism of dual delivery allowed larger, more mature blood vessels to be formed as opposed to smaller, incomplete vessels formed using a single factor delivery technique. ${ }^{24}$ Synthetic microsphere encapsulation has also been used to trap bFGF in PLGA, incorporating these microspheres into alginate scaffolds or simply injecting them with small intestinal submucosa and preadipocytes, both of which have been shown to significantly enhance vascularization. ${ }^{25,26}$ In terms of biodegradable microspheres, chitosan-gelatin microspheres containing bFGF have been developed and incorporated into a porous chitosan-gelatin scaffold, demonstrating initial fast release kinetics over 2 days before achieving a steady release profile lasting 2 weeks, displaying promise for vascularization. $^{27}$

Ultimately, the ability to direct the timing and release of growth factors will control the degree of vascularization within the tissue. ${ }^{28}$ To direct angiogenesis, it is critical to determine the release kinetics of the angiogenic factors from the scaffold. The time course of vascularization may not be compatible with maintaining cell viability throughout the construct; that is, cells at the center of the tissue undergo apoptosis before vascularization is complete. Because of this dependence on cell response (i.e., endothelial cell migration, proliferation, and organization into capillary-like structures) to vascularize the scaffold, these techniques are not highly controllable and do not directly consider the mass transfer requirements (i.e., oxygen and nutrients) of the cell-seeded scaffold (Table 2). Thus, these techniques may be more effectively employed as a means of enhancing vascularization in the context of quantitative scaffold design, where cellular metabolism and cell density are accounted for and gradients of vascular factors may be established through their controlled release, ultimately driving the development of the required vasculature. Further, cues from native vasculogenesis and angiogenesis may be applied to scaffold design, presenting a physiologically relevant time course of release. In natural vasculogenesis, differentiation and formation of angioblasts into primitive blood vessels is induced by VEGF receptor activation, with concentration gradients and maintenance of threshold levels required for differentiation and angiogenesis. ${ }^{29}$ Sprouting of new vessels through angiogenesis is then induced by angiopoietins, ligands for the endothelial cell receptor kinase TIE, which modulates VEGF activity and may direct angiogenesis through the pattern of signaling by VEGF and TIE receptors (TIE- 1 and TIE-2). ${ }^{30}$ Immature vessels are stabilized by recruiting vascular smooth muscle cells (SMCs) and pericytes as well as generating ECM, with this maturation and remodeling process regulated largely by PDGF and transforming growth factor$\beta 1$, with perfusion, shear stress, and oxygenation playing critical roles, ultimately rendering the endothelial cells independent of VEGF. ${ }^{31,32}$ Further branching and remodeling is controlled by matrix metalloproteinase activity, influencing cell migration and differentiation through the release of pro-angiogenic factors within the matrix. ${ }^{31}$ Scaffold design should apply this knowledge of the temporal expression profiles of these cytokines during vessel development in vivo to form biomaterial scaffolds loaded with these factors, specifically with control over release rates over time and thus vascular development.

\section{Scaffold design and engineering}

In addition to loading scaffolds with angiogenic factors and controlling release profiles, the scaffolds themselves may be engineered to promote vascularization. Through scaffold

Table 2. Scaffold Functionalization Techniques for Vascular Tissue Engineering

\begin{tabular}{lcc}
\hline & Growth factor delivery & Scaffold design/engineering \\
\hline Mechanism of vascularization & $\begin{array}{c}\text { Recruitment of vascular cells via } \\
\text { angiogenic factor release } \\
\text { Wound healing; bone, adipose, and } \\
\text { Tissues and cell types cocultured }\end{array}$ & $\begin{array}{c}\text { Channels and alignment to promote } \\
\text { perfusion and cellular organization } \\
\text { Cardiac tissue; fibroblasts }\end{array}$ \\
$\begin{array}{c}\text { Quantitative measurement of } \\
\text { nutrient and oxygen diffusion }\end{array}$ & $\begin{array}{c}\text { Very limited } \rightarrow \text { laser Doppler to } \\
\text { measure perfusion in vivo }\end{array}$ & $\begin{array}{c}\text { Ultrasound imaging, } \mathrm{O}_{2} \text { distribution } \\
\text { with microelectrodes, modeling } \mathrm{O}_{2} \\
\text { gradients, nutrient diffusion chamber }\end{array}$ \\
$\begin{array}{c}\text { Points of functional anastomosis } \\
\text { References }\end{array}$ & None, only vascular cell recruitment & None reported, but could be designed \\
& $3,6,12-28$ & 5,44
\end{tabular}


design and engineering, issues of oxygen gradients and flow regimes, as well as cell alignment and angiogenesis, may be controlled (Table 2). In the field of tissue engineering, the ability to maintain suitable oxygen tensions and nutrient diffusion throughout the scaffold is critical for cell viability and function. One of the ways that this has been addressed is through the use of channeled scaffolds. Channeled scaffolds have been formed by incorporating phosphate-based glass fibers into collagen scaffolds or by using a laser cutting system to bore holes into a scaffold. ${ }^{5,33}$ By incorporating phosphate-based glass fibers into collagen scaffolds, channel size and distribution is controllable based on the original size of the glass fibers $(10-50 \mu \mathrm{m})$ and the fiber-to-fiber spacing. Thus, when these fibers are degraded, microchannels are left behind that offer potential for flow and improved cell viability. ${ }^{33}$ In a more tissue-specific approach, channeled scaffolds formed using a laser cutting system addressed previously observed issues of cell viability in constructs of rat neonatal myocytes seeded on collagen sponge scaffolds. ${ }^{34}$ In previous studies, a linear decrease in oxygen concentration was observed from the surface of the construct to the bottom, correlating with a decrease in cell viability. Cell viability was approximately $60 \%$ within $500 \mu \mathrm{m}$ of the surface, but quickly dropped to $5-15 \%$ at depths greater than $1000 \mu \mathrm{m}^{34}$ To address this issue, an elastomeric scaffold [poly(glycerol-sebacate)] was developed with a parallel array of channels ( $370 \mu \mathrm{m}$ in diameter, $410 \mu \mathrm{m}$ spacing) aimed at mimicking the capillary network and allowed for flow of culture medium throughout the construct. This approach, combined with addition of perfluorocarbons in the medium as oxygen carriers, produced significantly improved cardiac tissues based on total cell number, expression of markers of cardiac differentiation, and excitation thresholds. ${ }^{5}$

Besides microchanneling, directing scaffold vascularization through micro-patterning or molecular gradients has been explored, offering scaffold cues that can effectively dictate the migration and alignment of cells within the construct. Work with scaffold patterning has included the formation of grooved, porous poly-caprolactone scaffolds. These scaffolds were produced by mixing the poly-caprolactone with PLGA micro/nanoparticles and casting the polymer onto a grooved surface before leaching out the micro/ nanospheres. This process produces surfaces that are conducive for vascular cell alignment and also increase medium diffusion. ${ }^{35}$ By stacking these layers, it may be possible to build up three-dimensional (3D) tissues with cellular organization for blood vessel formation, an outcome that may also be directed by forming gradients within the scaffold. Previous gradient work has largely focused on migration of vascular cells in response to concentration or surface-density gradients of growth factors such as VEGF, bFGF, arginineglycine-aspartic acid (RGD)-peptide or fibronectin. ${ }^{36-39}$ While these studies have largely focused on surface gradients, gradients within 3D scaffolds are also being pursued. In a recent study, collagen-hyaluronic acid (HA) scaffolds were produced by mixing varying concentrations of HA, an inhibitor of angiogenesis, into collagen gels with the goal of controlling vascular sprout rate and direction. By implanting endothelial cell spheroids into these gels and monitoring the number, direction, and length of capillary-like sprouts, directionality and enhanced sprouting rates away from the HA gradient were found. ${ }^{40}$ These techniques, combined with previously described techniques for enhancing migration, offer powerful tools to control vascularization for tissue engineering.

Future scaffold designs may be improved through the use of an emerging tool, computer-aided tissue engineering, which can help model and design scaffolds with controlled internal and external architecture, particularly vascular channel elements of different sizes and shapes. ${ }^{41,42}$ Using tissue and/or scaffold imaging (computed tomography, magnetic resonance imaging, and optical microscopy) to generate computer-aided designed tissue or scaffold models, tissue engineering scaffolds can be built to match native features of porosity, mechanical strength, and vascularization, with the correct spatial positioning and morphology. ${ }^{41,42}$ Through these techniques a vascularized modular 3D scaffold may be developed with tight control over the vascular tree, vessel dimensions, and interconnectivity. ${ }^{41,43}$ Controlled spatial deposition of different biopolymers, growth factors, and cells may also be achieved as multi-nozzle systems have been developed. ${ }^{44}$ Overall, these scaffolding techniques offer fine control over vascularization potential and offer a multitude of options in scaffold design and engineering to create functional tissue outcomes.

\section{Cell-Based Techniques}

\section{Endothelial cell cocultures}

To help compensate for issues with growth factor delivery, cocultures with endothelial cells have been utilized to provide a starting point for vascularization; however, consideration for quantity of cells/vessels required for a particular tissue is critical. ${ }^{45,46}$ These techniques have been used for in vitro vascularization of a variety of tissues, including bone and adipose, with the endothelial cells introduced into the tissues via 3D multicellular spheroids or simple mixing of cultures. ${ }^{45,47}$ Endothelial cell spheroids produce capillarylike sprouts, especially in the presence of angiogenic factors such as VEGF and bFGF, or in coculture with fibroblasts, but sprout diameter and length was reduced in cocultures of endothelial cells and osteoblasts. ${ }^{45,46,48}$ In the case of fibroblasts, it has been shown that fibroblasts modulate endothelial cell network formation, suggesting the critical need for complex mixed spheroid cocultures to adequately mimic in vivo angiogenesis. ${ }^{49}$ Despite the successes achieved using these spheroid models, issues of functional anastomosis into host vasculature remain. For bone tissue engineering, endothelial cell and osteoprogenitor cell (human mesenchymal stem cells [hMSCs]) spheroid cocultures formed a prevascular network in vitro but, upon implantation in vivo, displayed no functional perfusion. ${ }^{50}$

Beyond spheroid cultures, simple cocultures of endothelial cells, fibroblasts, and other cell types have been used to grow vascularized skin, skeletal muscle, and bone tissues, among others. ${ }^{51-53}$ Through simple cocultures of different tissuespecific cell types in a biopolymer gel such as collagen or on porous polymer scaffolds, spontaneous formation of tubular structures was observed with expression of typical markers of microvasculature (Table 3). ${ }^{54-67}$ In several cases, the role of fibroblasts was critical for the formation and the maintenance of the microvasculature as they were associated with neosynthesis of ECM as well as increasing levels of VEGF. ${ }^{51,52}$ Another cell type, neural progenitor cells, has also shown the 
Table 3. Vascular Cell Markers at Different Stages of Differentiation

\begin{tabular}{|c|c|c|c|c|c|}
\hline \multicolumn{6}{|c|}{ Endothelial cell markers } \\
\hline \multicolumn{2}{|c|}{ Early/differentiation } & \multicolumn{2}{|c|}{ Constitutive phenotype } & \multicolumn{2}{|c|}{ Activated phenotype } \\
\hline Marker & Function & Marker & Function & Marker & Function \\
\hline CD34 & $\begin{array}{l}\text { Hematopoietic } \\
\text { precursor marker }\end{array}$ & PECAM-1 (CD31) & $\begin{array}{l}\text { Platelet/endothelial } \\
\text { cell adhesion } \\
\text { molecule-1; role } \\
\text { in leukocyte } \\
\text { recruitment, } \\
\text { migration }\end{array}$ & $\begin{array}{l}\text { VCAM-1 } \\
\text { (CD106) }\end{array}$ & $\begin{array}{l}\text { Vascular cell } \\
\text { adhesion } \\
\text { molecule-1; } \\
\text { upregulated by } \\
\text { inflammatory } \\
\text { cytokines }\end{array}$ \\
\hline $\begin{array}{l}\text { PECAM-1 } \\
\text { (CD31) }\end{array}$ & $\begin{array}{l}\text { Surface adhesion } \\
\text { molecule }\end{array}$ & eNOS & $\begin{array}{l}\text { Endothelial nitric } \\
\text { oxide synthase; } \\
\text { production of NO, } \\
\text { regulation of } \\
\text { vascular function }\end{array}$ & $\begin{array}{l}\text { ICAM-1 } \\
\text { (CD54) }\end{array}$ & $\begin{array}{l}\text { Intercellular } \\
\text { adhesion } \\
\text { molecule-1; } \\
\text { upregulated by } \\
\text { inflammatory } \\
\text { cytokines }\end{array}$ \\
\hline VE-cadherin & $\begin{array}{l}\text { Surface marker; } \\
\text { cell-cell junctions }\end{array}$ & Factor VIII & $\begin{array}{l}\text { Clotting factor in } \\
\text { thrombotic } \\
\text { pathway }\end{array}$ & $\begin{array}{l}\text { E-selectin } \\
\quad(\text { CD62E) }\end{array}$ & $\begin{array}{l}\text { Inflammation-induced } \\
\text { adhesion molecule }\end{array}$ \\
\hline & & VE-cadherin & $\begin{array}{l}\text { Cell-cell junctions, } \\
\text { demonstrates } \\
\text { confluent } \\
\text { endothelium } \\
\text { von Willebrand } \\
\text { factor, clotting } \\
\text { protein }\end{array}$ & $\begin{array}{l}\text { P-selectin } \\
\text { (CD62P) }\end{array}$ & $\begin{array}{l}\text { Cytokine-activated } \\
\text { adhesion molecule }\end{array}$ \\
\hline
\end{tabular}

SMC markers

\begin{tabular}{|c|c|c|c|c|c|}
\hline \multicolumn{2}{|c|}{ Early/differentiation } & \multicolumn{2}{|c|}{ Synthetic phenotype } & \multicolumn{2}{|c|}{ Contractile phenotype } \\
\hline Marker & Function & Marker & Function & Marker & Function \\
\hline $\operatorname{SM} \alpha$-actin & $\begin{array}{l}\text { Contractile protein } \\
\text { of SMCs; first } \\
\text { marker of } \\
\text { differentiated } \\
\text { SMCs }\end{array}$ & $\downarrow$ SM $\alpha$-actin & $\begin{array}{l}\text { Contractile protein } \\
\text { of SMCs }\end{array}$ & $\uparrow \mathrm{SM} \alpha$-actin & $\begin{array}{l}\text { Contractile protein } \\
\text { of SMCs }\end{array}$ \\
\hline Calponin & $\begin{array}{l}\text { Potential regulator } \\
\text { of SM contraction }\end{array}$ & $\downarrow$ Calponin & $\begin{array}{l}\text { Potential regulator } \\
\text { of SM contraction }\end{array}$ & $\uparrow$ Calponin & $\begin{array}{l}\text { Potential regulator } \\
\text { of SM contraction }\end{array}$ \\
\hline SM-22- $\alpha$ & $\begin{array}{l}\text { Calponin-related } \\
\text { cytoskeletal } \\
\text { protein } \\
\text { SMC-specific } \\
\text { marker }\end{array}$ & $\begin{array}{l}\uparrow \text { SMemb/ } \\
\text { NMHC-B }\end{array}$ & $\begin{array}{l}\text { Embryonic/nonmuscle } \\
\text { isoform of myosin } \\
\text { heavy chain }\end{array}$ & $\uparrow \mathrm{SM}-\mathrm{MHC}$ & $\begin{array}{l}\text { Smooth muscle } \\
\text { myosin heavy } \\
\text { chain essential } \\
\text { component of } \\
\text { contractile system }\end{array}$ \\
\hline Caldesmon & $\begin{array}{l}\text { Protein that binds } \\
\text { calmodulin, } \\
\text { actin, myosin }\end{array}$ & $\downarrow$ Caldesmon & $\begin{array}{l}\text { Binds } \mathrm{Ca}^{2+} \text {-calmodulin, } \\
\text { actin, myosin; } \\
\text { mediates } \\
\mathrm{Ca}^{2+} \text {-depandent } \mathrm{SM} \\
\text { contraction inhibition }\end{array}$ & $\uparrow$ Caldesmon & $\begin{array}{l}\text { Binds calmodulin, } \\
\text { actin, myosin; } \\
\text { mediates } \\
\mathrm{Ca}^{2+} \text {-dependent } \\
\mathrm{SM} \text { contraction } \\
\text { inhibition }\end{array}$ \\
\hline \multirow[t]{2}{*}{ Tropomyosin } & $\begin{array}{l}\text { Rod-like proteins } \\
\text { in tight association } \\
\text { with action }\end{array}$ & $\downarrow$ Tropomyosin & $\begin{array}{l}\text { Binds to actin grooves; } \\
\text { mediates } \\
\mathrm{Ca}^{2+} \text {-dependent } \\
\text { regulation of } \\
\text { actin-myosin } \\
\text { interaction }\end{array}$ & $\uparrow$ Tropomyosin & $\begin{array}{l}\text { Binds to actin } \\
\text { grooves; } \\
\text { mediates } \\
\mathrm{Ca}^{2+} \text {-dependent } \\
\text { regulation of } \\
\text { actin-myosin } \\
\text { interaction }\end{array}$ \\
\hline & & & & Elastin & $\begin{array}{l}\text { Extracellular matrix } \\
\text { protein; source of } \\
\text { vessal compliance }\end{array}$ \\
\hline
\end{tabular}

References [49-62]

PECAM-1, platelet/endothelial cell adhesion molecule-1; VE-cadherin, vascular endothelial cadherin; eNOS, endothelial nitric oxide synthase; vWF, von Willebrand factor; VCAM-1, vascular cell adhesion molecule-1; ICAM-1, intercellular adhesion molecule-1; SM, smooth muscle; NMHC-B, non-muscle myosin heavy chain-B; MHC, myosin heavy chain. 
ability to enhance tubular formation both in vitro and in forming a functional microcirculation in vivo. ${ }^{68}$ Together, these results underlie the complexity of cell-cell signaling, cytokine release, and growth factor delivery in forming a functional microvasculature. Combining layers of endothelial cells and layers of other cells, such as fibroblasts, within native hydrogels has been pursued. By spacing a layer of dermal fibroblasts at a distance $1.8-4.5 \mathrm{~mm}$ from human umbilical vein endothelial cell-coated beads within a fibrin gel fed with media containing VEGF and bFGF, endothelial cells produced capillaries based on the distance of the endothelial cells from the fibroblasts. ${ }^{69}$ This approach could help dictate the formation of a vascular network in an engineered tissue in vitro, although without control over number and spacing of vessels or means of functional anastomosis to blood vessels in vivo (Table 4).

\section{Growth factor-producing cells}

An additional cell-based approach that has become a focus of vascular research is the transfection of cells to overexpress angiogenic factors. These cells can be seeded within biomaterial scaffolds and release cytokines that modulate vascular cell migration, proliferation, and maturation into tubular vessels in a more controlled, biomimetic manner than simple scaffold loading (Table 4). In a study aimed at producing tissue engineered bone, combinations of scaffolds were coated with or without VEGF-plasmid DNA and loaded with hMSCs transfected with or without the VEGF plasmid. ${ }^{70}$ Compared to controls, VEGF plasmid-coated scaffolds and VEGF-transfected cells demonstrated significantly enhanced vascularization, osteogenesis, and scaffold resorption compared to control groups, with the VEGF-transfected cells producing the highest rate of vascularization. ${ }^{70}$ Similarly, rat MSCs transfected with VEGF before injecting the transfected cells into the infarct zones of an ischemic rat heart model was studied to stimulate revascularization. ${ }^{71}$ Compared to control injections of nontransfected cells, plasmid alone, and media, the hearts injected with the VEGF-transfected cells displayed the greatest reduction in infarct size, best heart function, and the greatest capillary density. ${ }^{71}$ In addition to these transfection-based approaches, recent results using MSCs derived from human peripheral blood indicate that these cells secrete VEGF and induce vascularization in a mouse skin defect model. ${ }^{72}$ As opposed to growth factor scaffold-loading-based techniques, these cell-based approaches demonstrate significant potential for sustained growth factor release over time and better overall vascularization.

\section{Bioreactor Designs}

\section{Rotating bioreactors}

In generating tissues in vitro, bioreactor systems are often used to perfuse culture medium through a porous scaffold to try to maintain cell viability in the middle and homogeneity throughout the construct. ${ }^{73}$ While these efforts generally improve outcomes, these improvements do not solve problems of heterogeneity in tissue outcomes due to fluid flow along paths of least resistance. More significantly, these approaches do not address the transition and integration of the tissue grown in vitro to an in vivo setting. Specifically, these tissue constructs do not develop a functional vasculature that offers points of anastomosis to host vessels in vivo (Table 5).

Work using rotating bioreactors has been primarily confined to endothelial cell culture on microcarrier beads using a horizontal rotating bioreactor originally developed by NASA. ${ }^{74,75}$ The horizontally rotating bioreactors, or slowturning lateral vessels, were designed as a rotating cylinder of culture medium, with a gas-permeable membrane for oxygen and carbon dioxide exchange, and fittings for sampling or medium exchange. ${ }^{75,76}$ The speed of the rotation could be controlled to match the settling velocity of the tissue constructs, keeping them suspended within the vessel. This approach has been used for engineering of bone, cartilage, and cardiac tissue. ${ }^{76-79}$ In terms of vascularized tissue engineering, early events (growth and differentiation) of ocular angiogenesis have been studied in these bioreactors, using human retinal cells and bovine endothelial cells in coculture on microcarrier beads and grown in the horizontally rotating bioreactors for up to 5 weeks. In coculture, the endothelial cells formed cords and capillary-like structures as well as the beginning of sprouts, indicators of a developing vasculature. $^{75}$

\section{Perfusion bioreactors}

In addition to rotating vessels, a wide variety of perfusion bioreactors have been developed to address issues of oxygen and nutrient transport throughout tissue engineered scaffolds. These devices have been used in the culture of several tissue types, including bone, adipose, and cardiac, among others. ${ }^{73,80-82}$ While these studies support a variety of designs and tissue types, they still lack a vascular component (Table 5). Vascular perfusion bioreactors typically focus on producing a tissue-engineered blood vessel, not on vascularizing another tissue type. Using pulsatile conditions typically found in vivo, functional arteries may be grown in vitro

Table 4. Cell-Based Techniques for Vascular Tissue Engineering

\begin{tabular}{|c|c|c|}
\hline & Endothelial cell cocultures & Growth factor-producing cells \\
\hline Mechanism of vascularization & $\begin{array}{l}\text { Use of endothelial cells to } \\
\text { form capillary-like structures }\end{array}$ & $\begin{array}{l}\text { Transfected cells used to modulate } \\
\text { angiogenic growth factor delivery }\end{array}$ \\
\hline Tissues and cell types cocultured & $\begin{array}{l}\text { Skin, bone, adipose, and muscle } \\
\text { tissue; fibroblasts, neural } \\
\text { progenitor cells }\end{array}$ & Bone, myocardial, and dermal tissue \\
\hline $\begin{array}{l}\text { Quantitative measurement of } \\
\text { nutrient and oxygen diffusion }\end{array}$ & $\begin{array}{l}\text { Luciferase or other fluorescence-based } \\
\text { imaging, fiber optic oxygen sensors }\end{array}$ & None reported \\
\hline Points of functional anastomosis & None, requires ingrowth of host vessels & None, only vascular cell recruitment \\
\hline References & $45-53,68,69$ & $70-72$ \\
\hline
\end{tabular}


Table 5. Bioreactor Designs for Vascular Tissue Engineering

\begin{tabular}{|c|c|c|}
\hline & Rotating bioreactors & Perfusion bioreactors \\
\hline Mechanism of vascularization & $\begin{array}{l}\text { More efficient distribution of culture } \\
\text { medium throughout construct }\end{array}$ & $\begin{array}{l}\text { Mimic flow of vessels in vivo } \\
\text { to improve vascular cell } \\
\text { viability and function }\end{array}$ \\
\hline Tissues and cell types cocultured & $\begin{array}{l}\text { Bone, cartilage, and cardiac tissue; } \\
\text { retinal and mesenchymal stem cells }\end{array}$ & $\begin{array}{l}\text { Bone and cardiac tissue, small } \\
\text { arteries; mesenchymal stem } \\
\text { cells, SMCs, cardiomyocytes }\end{array}$ \\
\hline $\begin{array}{l}\text { Quantitative measurement of } \\
\text { nutrient and oxygen diffusion }\end{array}$ & $\begin{array}{l}\text { Limited } \rightarrow \text { dye-protein permeability, } \\
\text { bulk media metabolism analysis }\end{array}$ & $\begin{array}{l}\text { Limited } \rightarrow \text { dye tracers of } \\
\text { perfusion, media metabolism } \\
\text { analysis, modeling }\end{array}$ \\
\hline $\begin{array}{l}\text { Points of functional anastomosis } \\
\text { References }\end{array}$ & $\begin{array}{l}\text { None, requires ingrowth of host vessels } \\
74-79\end{array}$ & $\begin{array}{l}\text { Yes, for arteries grown in vitro } \\
73,80-88\end{array}$ \\
\hline
\end{tabular}

using different polymers (synthetic [polyglycolic acid, polyester] or natural [collagen, fibrin, silk]) and different cellseeding techniques (static or perfusion; SMCs, endothelial cells, or both). ${ }^{83-87}$ Only recently have vessels been used as a means of perfusing a larger tissue, such as the abdominal aorta of a rat as a core perfusion element within an artificial myocardial matrix of collagen and neonatal rat cardiomyocytes. ${ }^{88}$ The perfused tissues displayed enhanced cell viability and increased metabolic activity when compared to nonperfused controls. ${ }^{88}$ This approach has additional promise in that it provides points for functional anastomosis at each end of the vessel, offering translation from in vitro culture to an in vivo setting.

\section{MEMS-Related Approaches}

\section{Microfluidic design from synthetic polymers}

Microfabrication techniques have gained popularity as they offer fine control over the formation of a microvascular network. Through the fabrication of a negative mold, a complex capillary pattern may be formed and serve as a template for molding materials. ${ }^{89}$ These capillary networks may be perfused and endothelialized, providing a mimic of natural vasculature as well as oxygen and nutrient delivery and waste removal (Table 6). Standard techniques use plasma etching or lithographic techniques to produce desired features with micron-scale precision, with replica molds of PDMS cast from the negative feature molds. These molds may then be bonded with one another before seeding with endothelial cells to form cylindrical capillary channels. ${ }^{89}$ Direct-write assembly has been used to form 3D microfluidic devices for vascular tissue engineering. ${ }^{90}$ Recently, more biomimetic techniques have emerged to develop vascular networks that are representative of in vivo conditions. Computational modeling has been used to understand flow behavior for microfluidic systems based on physiological data. $^{91}$ Direct-write laser technology has been utilized to form multiple-depth channel systems with diameter changes between parent and daughter vessels that mimic physiological systems. ${ }^{92}$ In addition, techniques to deliver and measure oxygen content within a microvascular network could have broader implications in tissue engineering as a quantitative means of assessing vascular spacing. ${ }^{93}$

Despite all of these advances, because these systems are typically formed from nondegradable materials such as PDMS, they offer limited use in vivo due to issues of biofouling, nondegradability, and limited integration to surrounding tissues. Further, limited integration with host vasculature is an issue, with surgical removal required at prescribed time frames, compounding the challenge of repair and function. As a result, more recent approaches have focused on degradable microfluidic systems to address these issues.

\section{Biodegradable microfluidics}

To address issues of biocompatibility that are typically observed with synthetic, nondegradable materials such as PDMS or silicone, biocompatible and biodegradable materials for microfluidic applications are being pursued. ${ }^{94}$ Elastomers such as poly(glycerol sebacate) (PGS) that are biocompatible and biodegradable have been explored for

Table 6. Microelectromechanical Systems-Related Approaches to Vascular Tissue Engineering

\begin{tabular}{lcc}
\hline Mechanism of vascularization & Synthetic polymer microfluidics & Biodegradable microfluidics \\
Tissues and cell types cocultured & $\begin{array}{c}\text { Micromolding to replicate vascular tree, } \\
\text { seed with endothelial cells }\end{array}$ & $\begin{array}{c}\text { Micromolding capillary network } \\
\text { using biodegradable substrates } \\
\text { (vascular tree) }\end{array}$ \\
$\begin{array}{c}\text { Quantitative measurement of } \\
\text { nutrient and oxygen diffusion } \\
\text { chondrocytes }\end{array}$ & $\begin{array}{c}\text { Dye mixing/diffusion, flow/pressure } \\
\text { experiments, oxygen sensitive dyes, } \\
\text { computational modeling }\end{array}$ & $\begin{array}{c}\text { Fluorescent dye perfusion/diffusion, } \\
\text { diffusion and transport rate modeling }\end{array}$ \\
$\begin{array}{l}\text { Points of functional anastomosis } \\
\text { References }\end{array}$ & $\begin{array}{c}\text { None, poor in vivo integration } \\
89-93\end{array}$ & $\begin{array}{c}\text { None reported, but could be designed } \\
94-96,98-100\end{array}$ \\
\hline
\end{tabular}


vascular tissue engineering. ${ }^{94,95}$ Devices are produced using similar techniques as synthetic microfluidics, with PGS layers formed by casting onto negative molds, released using a sacrificial layer, and bonded together by physically adhering and curing the films under vacuum. By subsequently stacking single-layer microfluidic networks, with consideration for oxygen limitations, 3D scaffolds with complex vascular microchannels can be produced for different tissue types. ${ }^{95}$ Similar techniques have been applied to forming microvascular networks from a natural protein biopolymer, silk fibroin. ${ }^{96}$ Silk is a biocompatible and biodegradable protein derived from cocoons of the Bombyx mori silkworm and can be processed under aqueous conditions, be chemically functionalized, and promote cellular adhesion. Silk is also a mechanically robust material with slow, controllable degradation, making it a useful material for microfabrication for tissue-based applications. ${ }^{96,97}$ By casting silk onto negative molds, treating with methanol to form micromolded waterstable films, and binding to a flat layer using aqueous silk solution, microfluidic devices composed entirely of silk protein are produced. These devices have demonstrated improved mechanical properties compared to PGS films and also support hepatocyte culture, making these a promising option for degradable microfluidics. ${ }^{96}$

In addition to stacking different layers of biodegradable materials, other approaches to building 3D vascularized constructs have focused on creating microfluidic networks within cell-seeded hydrogels, including alginate, collagen, and fibrin. Using calcium alginate as a scaffold, a lithographic process was used to form microfluidic hydrogel networks seeded with chondrocytes. ${ }^{98}$ Channels of $100 \mu \mathrm{m}$ in diameter were formed within the gel, and the diffusion of fluorescent molecules, cell viability within the gel, and microchannel spacing were characterized to maintain a uniform metabolic environment throughout the bulk of the scaffold. In addition, two independent networks were incorporated into the hydrogel, maintaining steady-state gradients throughout the gel for both reactive and nonreactive solutes. These characterizations with respect to fluorescein, rhodamine, and calcein-acetoxymethylester (AM) were all done quantitatively, calculating values for the diffusion coefficients of the fluorescent molecules, rates of cell metabolism, and the Krogh length for characteristic variations in concentrations, among others. ${ }^{98}$ Similar lithographic techniques have been used to micropattern collagen gels, using a sacrificial digestion of patterned Matrigel embedded within the gel to produce micron-sized cavities. ${ }^{99}$ Using a slightly different approach, gelatin meshes were used to form a capil- lary network, micromolding the meshes in microfluidic networks before embedding within a collagen or fibrin hydrogel, melting and flushing the hydrogel, and perfusing with macromolecules and particles of interest. ${ }^{100}$ Channels $50 \mu \mathrm{m}$ in width were produced and could be seeded with endothelial cells to form an endothelialized network within a fibroblast-seeded hydrogel, a rudimentary vascularized tissue. As with the alginate work, transport within these capillary networks was quantitatively characterized in terms of diffusion rates under different flow conditions using fluorescent molecules. ${ }^{100}$ By coupling quantitative modeling and comparative analysis between expected and experimental results, it is possible to generate microfluidic networks for specific tissue types (Table 6). This approach serves as a critical point in the future of tissue vascularization.

\section{Modular Assembly \\ Endothelial cell-coated modules}

An emerging technique for producing prevascularized tissues involves the modular assembly of endothelialized microtissues to form a macrotissue. These microtissues may be generated through gravity-enforced self-assembly of primary cells or via seeding of collagen gels with a desired cell type. ${ }^{101-103}$ The microtissue modules are then coated with endothelial cells before combining in a mold or large tube to form a macrotissue. These packed-bed macrotissues can be perfused with medium or whole blood, or be connected to host vasculature through the use of a chicken chorioallantoic membrane assay. ${ }^{101-103}$ This technique has been used to generate tissues using hepatocytes, chondrocytes, and SMCs. The critical endothelial cell component on the module surface is what allows for functional perfusion by acting as an antithrombogenic surface, delaying clotting times, and inhibiting loss of platelets. ${ }^{102,104}$ However, while these modular tissues demonstrate the ability to be perfused as well as integrate with host vasculature over time, they do not replicate the tree-like vasculature exhibited in vivo and do not facilitate tissue integration in vivo by providing components that enable immediate anastomosis to host vasculature (Table 7).

\section{Vessel-embedded hydrogels}

Another developing modular approach is the perfusion of single- or multi-channel hydrogels. These systems are promising given that they can address two of the underlying issues with vascularization, measurement of oxygen/nutrient

Table 7. Modular Assembly Approaches to Vascular Tissue Engineering

\begin{tabular}{|c|c|c|}
\hline & Endothelial cell-coated modules & Vessel-embedded hydrogels \\
\hline Mechanism of vascularization & $\begin{array}{l}\text { Perfusion of packed bed of endothelial } \\
\text { cell-coated microtissues }\end{array}$ & $\begin{array}{l}\text { Perfusion of single- or multi-channel } \\
\text { hydrogels }\end{array}$ \\
\hline Tissues and cell types cocultured & Hepatocytes, chondrocytes, SMCs & $\begin{array}{l}\text { Perivascular cells, SMCs, mesenchymal } \\
\text { stem cells }\end{array}$ \\
\hline $\begin{array}{l}\text { Quantitative measurement of } \\
\text { nutrient and oxygen diffusion }\end{array}$ & $\begin{array}{l}\text { Limited } \rightarrow \text { modeling flow profiles } \\
\text { and porosity }\end{array}$ & $\begin{array}{l}\text { Fluorescent dye perfusion/diffusion, } \\
\text { diffusion and transport rate modeling }\end{array}$ \\
\hline Points of functional anastomosis & None, requires ingrowth of host vessels & Yes, for one inlet/outlet designs \\
\hline References & $101-104$ & $105-107$ \\
\hline
\end{tabular}


Table 8. IN Vivo Approaches to Vascular Tissue Engineering

\begin{tabular}{|c|c|c|}
\hline & Polysurgery techniques & Arteriovenous loops \\
\hline Mechanism of vascularization & $\begin{array}{l}\text { Cell sheet engineering with } \\
\text { intervals of surgery to continue } \\
\text { vascularization in vivo }\end{array}$ & $\begin{array}{l}\text { Angiogenesis from arteriovenous } \\
\text { shunt within chamber in vivo }\end{array}$ \\
\hline Tissues and cell types cocultured & Cardiac, cornea, trachea, epithelial & Cardiac, bone, skeletal muscle, skin \\
\hline $\begin{array}{l}\text { Quantitative measurement of } \\
\text { nutrient and oxygen diffusion }\end{array}$ & None reported & $\begin{array}{l}\text { Hypoxia staining, angiography in } \\
\text { large models }\end{array}$ \\
\hline Points of functional anastomosis & $\begin{array}{l}\text { Yes, for cell sheets vascularized } \\
\text { directly over an existing host } \\
\text { artery and/or vein }\end{array}$ & $\begin{array}{l}\text { Yes, vein or synthetic graft forms the } \\
\text { shunt loop }\end{array}$ \\
\hline References & $108-110$ & 111-119 \\
\hline
\end{tabular}

diffusion, and connection with host vasculature (Table 7). Work on perfused vascular tubes embedded within collagen gels has produced vessels that display characteristics of native venules and capillaries, including barrier function, resistance to leukocyte adhesion, and inflammatory stimulus response. ${ }^{105}$ These microvessels were produced by embedding a $120-\mu \mathrm{m}$-diameter needle within a collagen gel, removing it, and seeding with endothelial cells. Upon maturation of the vessel, barrier function and leukocyte adhesion was assessed under perfusion, including quantitative evaluation of tube permeability in the absence or presence of histamine or thrombin, two inflammatory agonists, using fluorescently labeled bovine serum albumin or dextran. ${ }^{105}$ These studies provide fundamental insight into vascular development and perfusion, serving as potential building blocks for more complex studies, including the perfusion of multiple microvessels. By seeding SMCs onto strands of nylon line within a perfusion chamber, a parallel array of microvessels was formed that could be connected to a perfusion system. ${ }^{106}$ The SMCs on the lines proliferated over a 21-day culture, at which time the perfusion chamber was filled with agar, the nylon was removed, and the microvessels were perfused. The ability of multiple microvessels to be perfused using one inlet and outlet suggests that functional anastomosis may be achieved in vivo with slight modification of the system. Combinations of these approaches involving perfusion bioreactors and multiple microvessels may represent the most straightforward and productive approach to in vitro tissue vascularization.

Recent efforts have focused on bridging the gap between quantitative modeling of diffusion for proper vessel spacing and functional anastomosis for in vivo applications using silk microtube-hydrogel composite systems for vascular applications. ${ }^{107}$ Using hMSCs and human umbilical vein endothelial cells as the primary cell types, cell viability and differentiation as a function of distance from a single silk microtube in a perfused or statically cultured system can be studied. These results, in combination with oxygen and nutrient diffusion modeling and measurement, would dictate the critical spacing of microtube vessels and the overall dimensions of minimally sized modular elements. These tissues would be built from these minimal functional units, connected with one another to form one inlet and one outlet of perfusion and serve as sites of integration into host vasculature. This approach could address the major limiting factors in the field of prevascularization, providing a framework for building larger, more complex tissues.

\section{In Vivo Systems}

\section{Polysurgery techniques}

Beyond efforts to build vascularized tissues in vitro, researchers have used cell sheet engineering and polysurgery techniques to produce tissues up to $1 \mathrm{~mm}$ in thickness (Table 8). Cell sheet engineering techniques have been used in corneal surface reconstruction, blood vessel grafts, and myocardial tissue engineering, among others. ${ }^{58,108,109}$ To form vascularized myocardium, confluent sheets of neonatal rat cardiomyocytes were grown and stacked to form tissues up to $\sim 80 \mu \mathrm{m}$ in thickness, the limit for this particular cell and tissue type. ${ }^{110}$ To overcome this limitation, the layered cell sheets were transplanted into rats and allowed to vascularize over a period of 1-3 days. Upon complete vascularization of the transplant, another cell sheet was added and vascularized, continuing in this layer-by-layer transplantation approach until a $\sim 1$-mm-thick myocardium was achieved. Further, by directly transplanting the cell sheets over an existing host artery and vein, points of anastomosis were incorporated into the growing tissue to serve as points of connection when transplanting the engineered tissue from one host to another. ${ }^{110}$ As with the in vitro systems with one inlet and outlet aimed at translating to in vivo implantation, this system provides the critical vascular blood flow to supply the cells with the oxygen, nutrients, and waste removal that impart immediate functionality to the tissue upon connection of the prevascular structure to the host blood vessels.

\section{AV loops}

Another in vivo system that utilizes host blood vessels to develop prevascular structures is the culture of scaffolds within AV loop chambers. In this intrinsic vascularization model, a vein or synthetic graft is used to form a shunt loop between an artery and a vein and is enclosed within a chamber that is either empty or housing an ECM scaffold to be vascularized. ${ }^{111-113}$ Using an empty AV loop in a rat model, constructs formed extensive arteriole-capillaryvenule networks within a fibrin matrix exuded from the AV loop, with initial development occurring between 7 and 10 days and maturing over time. This maturation occurred with a concurrent decrease in hypoxia staining, which was prevalent during the 7-10 days, but decreased over time and was absent from the 28 day time point onward. ${ }^{111}$ Similar models have been used to incorporate ECM scaffolds such as 
collagen-glycosaminoglycan within the AV loop chamber by embedding the AV loop within two scaffolds and suturing to secure the loop. As in the empty chamber model, extensive new tissue growth and vascularization was observed, though alterations in the scaffold pore size and biochemical loading may further improve, direct, and control neoangiogenesis within the AV loop. ${ }^{114}$ Additional complexity may also be incorporated into the AV loop by adding cells to the scaffold before implantation. By mixing neonatal rat cardiomyocytes in Matrigel before incorporating the matrix within the AV loop culture chamber, spontaneously contracting constructs were developed that demonstrate organized assembly, are highly vascularized, and approach thicknesses of approximately $2 \mathrm{~mm} .{ }^{115}$ In general, this approach represents a significant step forward in vascularization of tissues and has been applied in a variety of tissue types including cardiac, bone, and skeletal muscle tissue (Table 8). ${ }^{116,117}$ Further, work beyond the small animal model of the rat and into larger animal models such as sheep, afford the ability to monitor vascularization in real-time using angiography techniques and complex 3D reconstructions demonstrating the power of this model system. ${ }^{118}$ Despite these successes, however, the rapid vascularization necessary for adequate cellular oxygen supply upon implantation is still lacking, but could be improved through prevascularization in vitro before implantation or biochemically modifying scaffolds to stimulate angiogenesis and cell proliferation in situ. ${ }^{119}$ These methods, combined with improved imaging techniques for monitoring angiogenesis and oxygen tensions in vivo, could ultimately provide the time course for clinically relevant vascularization of engineered tissues.

\section{Oxygen Modeling, Measurement, and Integration in Vascularized Tissues}

\section{Modeling of oxygen transport}

Beyond the techniques for vascularization, there is a clear need for detailed modeling of oxygen distribution in an engineered tissue construct. In vivo, oxygen and nutrients are supplied over physiological distances by the vasculature, with local transport dictated by intracapillary resistance, vascular permeability, interstitial flow, and cell metabolism. ${ }^{120,121}$ Capillary hematocrit, diffusion through the en- dothelium, physicochemical properties of the diffusing molecules, composition of the ECM, and rates of consumption all have critical effects on oxygen and nutrient transport. Thus, accurate modeling of engineered tissues in vitro should consider these issues as well. ${ }^{122,123}$

In considering oxygen transport, the most basic modeling components to be described are fluid flow, oxygen diffusion, and oxygen consumption. Within a cultivated tissue, the inflow of oxygen may be supplied by diffusion or a vascular element as described above (e.g., silk tube and channeled scaffold). Previous efforts to model oxygen gradients in vascular systems have largely focused on one-dimensional (1D), steady-state transport.

For tissues cultivated under static (non-agitated batch culture) conditions, the supply of oxygen is dictated by its effective diffusivity (Fig. 2A). These tissues are typically modeled using Fick's law:

$$
\mathrm{J}_{\mathrm{t}}=-\mathrm{D}_{\mathrm{t}} \frac{\partial \mathrm{C}_{\mathrm{O}_{2}}^{\mathrm{t}}}{\partial \mathrm{x}}
$$

where $J_{t}$ is the diffusive flux in the tissue $\left[\mathrm{mol} /\left(\mathrm{m}^{2} \cdot \mathrm{s}\right)\right], \mathrm{D}_{\mathrm{t}}$ is the diffusion coefficient of oxygen in the tissue $\left[\mathrm{m}^{2} / \mathrm{s}\right], \mathrm{C}_{\mathrm{O}_{2}}^{\mathrm{t}}$ is the tissue oxygen concentration $\left[\mathrm{mol} / \mathrm{m}^{3}\right]$, and $\mathrm{x}$ is the distance $[\mathrm{m}]$ into the tissue from the vascular element (or other source of oxygen). ${ }^{124,125}$ To determine the oxygen distribution within a cell-seeded construct, a consumption term needs to be specified to account for the rate of oxygen consumption of the growing cells. This consumption term is typically expressed assuming Michaelis-Menten kinetics:

$$
\mathrm{q}=\frac{\mathrm{q}_{\mathrm{max}} \mathrm{C}_{\mathrm{O}_{2}}^{\mathrm{t}}}{\mathrm{K}_{\mathrm{m}}+\mathrm{C}_{\mathrm{O}_{2}}^{\mathrm{t}}}
$$

where $\mathrm{q}$ is the rate of oxygen consumption per cell [mol/(cell-s)], $\mathrm{q}_{\max }$ is the maximum rate of oxygen consumption per cell $[\mathrm{mol} /(\mathrm{cell} \cdot \mathrm{s})]$, and $\mathrm{K}_{\mathrm{m}}$ is the MichaelisMenten constant $[\mu \mathrm{M}]$. If the value of $K_{m}(0.01-6.9 \mu \mathrm{M}$ for multiple cell types) ${ }^{125-127}$ is much smaller than the average oxygen concentrations in the vasculature $(130$ and $54 \mu \mathrm{M}$ in arterial and venous blood, respectively), ${ }^{127}$ the reaction rate can be assumed to be zero order: ${ }^{128}$

$$
q=q_{\max }
$$
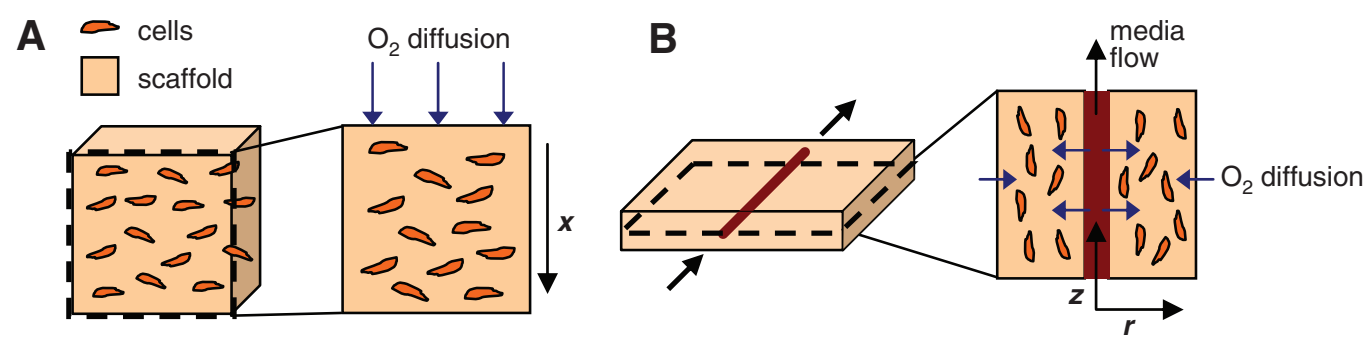

FIG. 2. Basic geometries for modeling oxygen diffusion and consumption. (A) Static cell-seeded scaffold or hydrogel with uni-axial diffusion of oxygen. Oxygen diffusion is characterized by Fick's Law with oxygen gradients within the scaffold at steady state controlled by the concentration of cells and their corresponding metabolic rate, described by Michaelis-Menten kinetics. (B) Perfused cell-seeded scaffold or hydrogel with diffusion of oxygen from multiple boundaries. Oxygen diffusion and consumption may be described using Fick's Law and Michaelis-Menten kinetics, respectively, with the flow of media described by the Navier-Stokes equations. These more complex geometries require careful consideration of boundary conditions, diffusion coefficients, and metabolic rates to accurately model oxygen gradients within the engineered tissue. Color images available online at www.liebertonline.com/ten. 
The volumetric rate of oxygen consumption (Q) $\left[\mathrm{mol} /\left(\mathrm{m}^{3} \cdot \mathrm{s}\right)\right]$ is obtained by multiplying $\mathrm{q}$ by the concentration of cells $\left(\mathrm{C}_{\text {cell }}\right)$ [cells $\left./ \mathrm{m}^{3}\right]$ :

$$
Q=C_{\text {cell }} \cdot q
$$

The steady-state distribution of $\mathrm{O}_{2}$ throughout the construct is then determined by solving the oxygen conservation equation:

$$
D_{t} \frac{\partial^{2} C_{O_{2}}^{t}}{\partial x^{2}}-Q=0
$$

with appropriate boundary conditions. In general, a homogeneous distribution of cells is assumed. If the oxygen consumption rate is also taken to be constant (Equation 3), an analytical solution can be derived. These basic equations can be applied to a variety of engineered tissues, including several different scaffold geometries (films, hydrogels, porous sponges, and composites) provided that the oxygen gradient is $1 \mathrm{D}$ and oxygen consumption is isotropic.

In tissues supplied by a flow of medium, oxygen convection and diffusion in the perfusing fluid must be taken into consideration (Fig. 2B). In the case of a capillary perfusing an engineered tissue, the Navier-Stokes equations may be used to describe the flow of an incompressible fluid. ${ }^{128}$ If the flow is taken to be steady, laminar, 1D, and fully developed, the equation for capillary flow in the $\mathrm{z}$-direction simplifies to

$$
\frac{\partial P}{\partial z}=\mu\left[\frac{1}{r} \frac{\partial}{\partial r}\left(r \frac{\partial v_{z}}{\partial r}\right)\right]
$$

where $\mathrm{z}$ is the axial direction, $\mathrm{r}$ is the radial direction, $\mathrm{P}$ is the pressure $[\mathrm{Pa}], \mu$ is the viscosity $[\mathrm{Pa} \cdot \mathrm{s}]$, and $\mathrm{v}_{\mathrm{z}}$ is the axial velocity $[\mathrm{m} / \mathrm{s}]$. The conservation equation for oxygen in the perfusing capillary can be written as:

$$
\mathrm{v}_{\mathrm{z}}(\mathrm{r}) \frac{\partial \mathrm{C}_{\mathrm{O}_{2}}^{\mathrm{c}}}{\partial \mathrm{z}}=\mathrm{D}_{\mathrm{c}}\left[\frac{1}{\mathrm{r}} \frac{\partial}{\partial \mathrm{r}}\left(\mathrm{r} \frac{\partial \mathrm{C}_{\mathrm{O}_{2}}^{\mathrm{c}}}{\partial \mathrm{r}}\right)+\frac{\partial^{2} \mathrm{C}_{\mathrm{O}_{2}}^{\mathrm{c}}}{\partial \mathrm{z}^{2}}\right]
$$

where $\mathrm{C}_{\mathrm{O}_{2}}^{\mathrm{c}}$ and $\mathrm{D}_{\mathrm{c}}$ are, respectively, the concentration and diffusion coefficient of oxygen in the capillary. Following specification of the boundary conditions, the flow velocity is computed first, and the oxygen concentration profiles in the perfusing capillary and the surrounding tissue are subsequently determined. Such a two-dimensional, steady-state analysis of a construct usually requires numerical computations, and models may be developed and solved using multi-physics modeling software such as FemLab (Comsol, Burlington, MA).

While these equations include the basic terms needed to model oxygen transport in tissue engineering, they are certainly not comprehensive. Within composite scaffolds, regions may need to be distinguished using different material properties or modeling equations, such as Darcy's Law for flow through a porous medium. Modeling of transient phenomena may also be performed to determine changes in oxygen gradients over time, necessitating that time derivatives be added to the equations described above. Other specific cases may require modeling the kinetics of oxygen dissociation from carriers, intracapillary resistance, vascular permeability, and pressure gradients. ${ }^{121,129}$ Nevertheless, the general equations and methods described above provide a basic framework for modeling oxygen distribution within 3D tissue constructs.

\section{Methods of oxygen measurement}

To accurately model oxygen transport, several techniques have been applied to measure the spatial distribution of oxygen within tissues. Gross measurements of oxygen in the bulk media within a bioreactor, or sampling at the inlet and outlet, have been performed using a blood-gas analyzer. ${ }^{76,130}$ While this method provides information on the $\mathrm{pH}$, oxygen, and carbon dioxide levels, at an accuracy of $2 \%$ for oxygen partial pressures, it does not provide information on oxygen tension within the construct. To partially address this issue, oxygen-sensitive dyes have been developed and incorporated into oxygen-sensing foils or microplates, either directly within a tissue matrix or as part of an oxygen microsensor probe. By incorporating an oxygen-sensitive dye into the foil or plate, phosphorescent intensity readings may be recorded and converted into oxygen tensions, ultimately yielding estimates of cellular oxygen consumption rates. ${ }^{131}$ Tissue samples or engineered constructs may be grown on these plates, and changes in the oxygen concentration in the tissue can be measured over weeks of culture. ${ }^{132}$ These systems, however, only measure oxygen concentration within one region of a construct and do not provide sufficient spatial sensitivity to measure differences in oxygen tensions as a function of depth without physical cross-sectioning of the samples before measurement.

To address this issue, oxygen microelectrodes have been developed to offer fine spatial resolution of oxygen measurements directly within a scaffold or tissue. These systems use gold-plated platinum wires, or glass optical fibers with a fluorescent probe at the end, to measure oxygen tension. ${ }^{133}$ For a platinum wire electrode, the probe is introduced into a substrate, the oxygen reacts with the cathode, and the resultant differences in the current flow are related back to oxygen tension based on two-point calibration using, for example, an air-saturated medium and an anoxic solution. ${ }^{34,133,134}$ In the case of a fluorescence-based probe, a pulsed blue light-emitting diode light is used to excite the sensor probe at the tip of the optical fiber. In the presence of oxygen, some of the excess energy is transferred to the oxygen molecule, quenching the fluorescence signal, with the decrease in fluorescence directly proportional to the oxygen tension in the sample. ${ }^{135}$ The microelectrodes have diameters as small as $5 \mu \mathrm{m}$ and, when used with a micromanipulator, offer spatial resolution on the order of $10 \mu \mathrm{m} .{ }^{134}$ These measurements may be performed in media, collagen hydrogels, polymer scaffolds, or tissue explants, under either static or flow conditions. ${ }^{34,125,134,136}$ Thus, these systems offer a wide variety of applications within tissue engineering, offering high levels of sensitivity and specificity. Despite this versatility, these probes are not suitable for all applications, particularly those involving more robust scaffolds where probes are subject to breaking due to their small size. In addition, the invasive nature of inserting a probe into a scaffold to measure oxygen tension may compromise scaffold integrity and sterility, necessitating a noninvasive method for measuring oxygen concentrations.

To measure oxygen tensions noninvasively, porphyrinbased oxygen-sensitive dyes used to prepare oxygen- 
sensitive foils have been prepared within aqueous media, injected in blood in vivo, or mixed directly within a tissue matrix. ${ }^{137-139}$ In each case, oxygen quenches the phosphorescence of albumin-bound porphyrins in a concentrationdependent manner, and the decay of the phosphorescent signal can be related back to oxygen tension $\left(\mathrm{P}_{\mathrm{O} 2}\right)$ using the Stern-Volmer equation ${ }^{131,140}$ :

$$
\tau_{o} / \tau=1+k_{q} \tau_{o}\left(P_{O_{2}}\right)
$$

where $\tau$ is the time constant of decay, $\tau_{\mathrm{o}}$ is the time constant of decay in absence of oxygen, and $k_{q}$ is a quenching constant; both constants $\tau_{\mathrm{o}}$ and $k_{q}$ are obtained by system calibration. ${ }^{141}$ Using this method, oxygen measurements can be achieved noninvasively. This method has previously been applied to characterize the in vivo oxygen tension within the vasculature or interstitial space of healthy and diseased mice. ${ }^{140,142,143}$ In terms of in vitro work, these phosphorescent dyes have been incorporated within collagen and alginate gels, seeded with chondrocytes, and cultured over a 24-h period, with oxygen distributions characterized both spatially and temporally. ${ }^{139}$ Porphyrin-based dyes have also been applied within microfluidic devices with tree-like vasculature to determine mass transfer characteristics. ${ }^{93}$ Future work should focus on bridging the gap between in vitro and in vivo measurements, with longer-term cultures in vitro and full characterization of the oxygen transport properties to ensure the maintenance of viable tissue in vivo.

\section{Integration of oxygen delivery and modeling in vascularized tissues}

In each of the preceding strategies for vascularizing engineered tissues, the role of oxygen delivery is critical for the survival of the cultured cells. However, this may be achieved not with vascularization, but with simple perfusion. In fact, in using some of the previously examined techniques, perfusion without any vascular cells was sufficient to supply oxygen throughout a scaffold. This applies in particular to channeled scaffolds and some of the microfluidic systems, demonstrating that perfusion can take place in a scaffold with no vessels as long as the scaffolds are highly porous and/or have low cell densities. This minimizes the distance of oxygen diffusion into the tissue as well as the volumetric rate of oxygen consumption, providing adequate oxygen supply for all cells within the scaffold. For scaffolds with low porosity or high cell density, however, these parameters are vastly increased, limiting the diffusion of oxygen to portions of the scaffold. By incorporating vascular cells into the engineered tissue, functional vessels may be formed, reducing capillary spacing and increasing the rate of oxygen supply throughout the construct. In addition, the development of these vessels provides connection points between the prevascularized tissue and host blood vessels, a critical point for translating a quantitatively designed perfused construct in vitro to a fully vascularized tissue in vivo.

\section{Conclusions and Future Directions}

The ability to vascularize tissues in vitro is currently a main focus within the field of tissue engineering. As perfusion and oxygen transport have direct effects on cell viability and differentiation, researchers are currently limited to tissues only a few millimeters in thickness. These limitations are imposed by mass transfer and are defined by the balance between the metabolic demand of the cellular components in the system and the size of the scaffold. As a result, reducing the distance for oxygen diffusion can only be addressed through perfusion and/or the development of a functional vasculature. Current approaches include growth factor delivery, channeled scaffolds, perfusion bioreactors, microfluidics, cell cocultures, cell functionalization, modular assembly, and in vivo systems. As discussed above, while these approaches may improve cell viability or generate capillary-like structures within a tissue construct, there is still a fundamental disconnect between defining the metabolic needs of a tissue through quantitative measurements of oxygen and nutrient diffusion and the potential ease of integration into host vasculature for future in vivo implantation. Thus, a combinatorial strategy to address the challenges of mass transport is needed to optimize in vitro approaches related to in vivo success in terms of oxygen and nutrient supply as well as connection with host blood vessels. The need to combine engineering design of scaffolds for implantation and modeling of mass transfer with relevant experimental data to build this foundation remains pervasive in the field, though quantitative techniques using biodegradable microfluidics and modular approaches are beginning to be more common.

Based on the above challenges and needs, we suggest that future work continue the development of the modularized approach to tissue engineering, where scaffold and tissue size, transport issues, and surgical implantation in vivo are considered from the outset. Using a quantitative approach to transport and design, minimally sized units could be derived from oxygen transport data and modeling, providing a basis for required capillary spacing on a tissue-specific basis. In addition, by targeting minimally sized units with the ability to be coupled with one another to generate larger systems, the ability for anastomosis with host vasculature in vivo would be maintained. Cues from previous work with growth factor delivery, directed scaffold assembly, and microfluidic coupling should also be considered and incorporated in these systems, but all with the ultimate design goals of quantitative assessment and functional anastomosis in mind. Importantly, this approach represents a generic strategy that can be employed by any laboratory, where specific variables (cell density, metabolic rate, etc.) can be imported into the design to determine minimally sized units for any cell type, biomaterial matrix, or target tissue.

\section{Acknowledgments}

We would like to acknowledge funding from the Tissue Engineering Resource Center through the National Institutes of Health (NIH) grant EB002520 from the National Institute of Biomedical Imaging and Bioengineering.

\section{Disclosure Statement}

No competing financial interests exist.

\section{References}

1. Jain, R.K., Au, P., Tam, J., Duda, D.G., and Fukumura, D. Engineering vascularized tissue. Nat Biotechnol 23, 821, 2005. 
2. Rouwkema, J., Rivron, N.C., and van Blitterswijk, C.A. Vascularization in tissue engineering. Trends Biotechnol 26, 434, 2008.

3. Zisch, A.H., Lutolf, M.P., and Hubbell, J.A. Biopolymeric delivery matrices for angiogenic growth factors. Cardiovasc Pathol 12, 295, 2003.

4. Zhang, G., and Suggs, L.J. Matrices and scaffolds for drug delivery in vascular tissue engineering. Adv Drug Deliv Rev 59, 360, 2007.

5. Radisic, M., Park, H., Chen, F., Salazar-Lazzaro, J.E., Wang, Y., Dennis, R., Langer, R., Freed, L.E., and VunjakNovakovic, G. Biomimetic approach to cardiac tissue engineering: oxygen carriers and channeled scaffolds. Tissue Eng 12, 2077, 2006.

6. Zisch, A.H., Lutolf, M.P., Ehrbar, M., Raeber, G.P., Rizzi, S.C., Davies, N., Schmokel, H., Bezuidenhout, D., Djonov, V., Zilla, P., and Hubbell, J.A. Cell-demanded release of VEGF from synthetic, biointeractive cell ingrowth matrices for vascularized tissue growth. FASEB J 17, 2260, 2003.

7. Bauer, S.M., Bauer, R.J., Liu, Z.J., Chen, H., Goldstein, L., and Velazquez, O.C. Vascular endothelial growth factor-C promotes vasculogenesis, angiogenesis, and collagen constriction in three-dimensional collagen gels. J Vasc Surg 41, 699, 2005.

8. Fiedler, U., and Augustin, H.G. Angiopoietins: a link between angiogenesis and inflammation. Trends Immunol 27, $552,2006$.

9. Andrae, J., Gallini, R., and Betsholtz, C. Role of plateletderived growth factors in physiology and medicine. Genes Dev 22, 1276, 2008.

10. Thurston, G., Suri, C., Smith, K., McClain, J., Sato, T.N., Yancopoulos, G.D., and McDonald, D.M. Leakage-resistant blood vessels in mice transgenically overexpressing angiopoietin-1. Science 286, 2511, 1999.

11. Friess, W. Collagen-biomaterial for drug delivery. Eur J Pharm Biopharm 45, 113, 1998.

12. Royce, P.M., Kato, T., Ohsaki, K., and Miura, A. The enhancement of cellular infiltration and vascularisation of a collagenous dermal implant in the rat by platelet-derived growth factor BB. J Dermatol Sci 10, 42, 1995.

13. Elcin, Y.M., Dixit, V., and Gitnick, G. Extensive in vivo angiogenesis following controlled release of human vascular endothelial cell growth factor: implications for tissue engineering and wound healing. Artif Organs 25, 558, 2001.

14. Huang, Y.C., Kaigler, D., Rice, K.G., Krebsbach, P.H., and Mooney, D.J. Combined angiogenic and osteogenic factor delivery enhances bone marrow stromal cell-driven bone regeneration. J Bone Miner Res 20, 848, 2005.

15. Kaigler, D., Wang, Z., Horger, K., Mooney, D.J., and Krebsbach, P.H. VEGF scaffolds enhance angiogenesis and bone regeneration in irradiated osseous defects. J Bone Miner Res 21, 735, 2006.

16. Kitajima, T., Terai, H., and Ito, Y. A fusion protein of hepatocyte growth factor for immobilization to collagen. Biomaterials 28, 1989, 2007.

17. Zhao, W., Han, Q., Lin, H., Gao, Y., Sun, W., Zhao, Y., Wang, B., Chen, B., Xiao, Z., and Dai, J. Improved neovascularization and wound repair by targeting human basic fibroblast growth factor (bFGF) to fibrin. J Mol Med 86, 1127, 2008.

18. Lin, H., Chen, B., Sun, W., Zhao, W., Zhao, Y., and Dai, J. The effect of collagen-targeting platelet-derived growth factor on cellularization and vascularization of collagen scaffolds. Biomaterials 27, 5708, 2006.
19. Steffens, G.C., Yao, C., Prevel, P., Markowicz, M., Schenck, P., Noah, E.M., and Pallua, N. Modulation of angiogenic potential of collagen matrices by covalent incorporation of heparin and loading with vascular endothelial growth factor. Tissue Eng 10, 1502, 2004.

20. Yao, C., Prevel, P., Koch, S., Schenck, P., Noah, E.M., Pallua, N., and Steffens, G. Modification of collagen matrices for enhancing angiogenesis. Cells Tissues Organs 178, 189, 2004.

21. Markowicz, M., Heitland, A., Steffens, G.C., and Pallua, N. Effects of modified collagen matrices on human umbilical vein endothelial cells. Int J Artif Organs 28, 1251, 2005.

22. Shen, Y.H., Shoichet, M.S., and Radisic, M. Vascular endothelial growth factor immobilized in collagen scaffold promotes penetration and proliferation of endothelial cells. Acta Biomater 4, 477, 2008.

23. Geiger, F., Bertram, H., Berger, I., Lorenz, H., Wall, O., Eckhardt, C., Simank, H.G., and Richter, W. Vascular endothelial growth factor gene-activated matrix (VEGF165GAM) enhances osteogenesis and angiogenesis in large segmental bone defects. J Bone Miner Res 20, 2028, 2005.

24. Richardson, T.P., Peters, M.C., Ennett, A.B., and Mooney, D.J. Polymeric system for dual growth factor delivery. Nat Biotechnol 19, 1029, 2001.

25. Perets, A., Baruch, Y., Weisbuch, F., Shoshany, G., Neufeld, G., and Cohen, S. Enhancing the vascularization of threedimensional porous alginate scaffolds by incorporating controlled release basic fibroblast growth factor microspheres. J Biomed Mater Res A 65, 489, 2003.

26. Marra, K.G., Defail, A.J., Clavijo-Alvarez, J.A., Badylak, S.F., Taieb, A., Schipper, B., Bennett, J., and Rubin, J.P. FGF2 enhances vascularization for adipose tissue engineering. Plast Reconstr Surg 121, 1153, 2008.

27. Liu, H., Fan, H., Cui, Y., Chen, Y., Yao, K., and Goh, J.C. Effects of the controlled-released basic fibroblast growth factor from chitosan-gelatin microspheres on human fibroblasts cultured on a chitosan-gelatin scaffold. Biomacromolecules 8, 1446, 2007.

28. Mikos, A.G., Herring, S.W., Ochareon, P., Elisseeff, J., Lu, H.H., Kandel, R., Schoen, F.J., Toner, M., Mooney, D., Atala, A., Dyke, M.E., Kaplan, D., and Vunjak-Novakovic, G. Engineering complex tissues. Tissue Eng 12, 3307, 2006.

29. Neufeld, G., Cohen, T., Gengrinovitch, S., and Poltorak, Z. Vascular endothelial growth factor (VEGF) and its receptors. FASEB J 13, 9, 1999.

30. Risau, W. Mechanisms of angiogenesis. Nature 386, 671, 1997.

31. Jain, R.K. Molecular regulation of vessel maturation. Nat Med 9, 685, 2003.

32. Carmeliet, $P$. Manipulating angiogenesis in medicine. J Intern Med 255, 538, 2004.

33. Nazhat, S.N., Neel, E.A., Kidane, A., Ahmed, I., Hope, C., Kershaw, M., Lee, P.D., Stride, E., Saffari, N., Knowles, J.C., and Brown, R.A. Controlled microchannelling in dense collagen scaffolds by soluble phosphate glass fibers. Biomacromolecules 8, 543, 2007.

34. Radisic, M., Malda, J., Epping, E., Geng, W., Langer, R., and Vunjak-Novakovic, G. Oxygen gradients correlate with cell density and cell viability in engineered cardiac tissue. Biotechnol Bioeng 93, 332, 2006.

35. Sarkar, S., Lee, G.Y., Wong, J.Y., and Desai, T.A. Development and characterization of a porous micro-patterned scaffold for vascular tissue engineering applications. Biomaterials 27, 4775, 2006. 
36. Liu, L., Ratner, B.D., Sage, E.H., and Jiang, S. Endothelial cell migration on surface-density gradients of fibronectin, VEGF, or both proteins. Langmuir 23, 11168, 2007.

37. DeLong, S.A., Moon, J.J., and West, J.L. Covalently immobilized gradients of bFGF on hydrogel scaffolds for directed cell migration. Biomaterials 26, 3227, 2005.

38. Burdick, J.A., Khademhosseini, A., and Langer, R. Fabrication of gradient hydrogels using a microfluidics/ photopolymerization process. Langmuir 20, 5153, 2004.

39. Smith, J.T., Elkin, J.T., and Reichert, W.M. Directed cell migration on fibronectin gradients: effect of gradient slope. Exp Cell Res 312, 2424, 2006.

40. Borselli, C., Oliviero, O., Battista, S., Ambrosio, L., and Netti, P.A. Induction of directional sprouting angiogenesis by matrix gradients. J Biomed Mater Res A 80, 297, 2007.

41. Nam, J., Starly, B., Darling, A., and Sun, W. Computer aided tissue engineering for modeling and design of novel tissue scaffolds. Comput Aided Des Appl 1, 633, 2004.

42. Sun, W., Darling, A., Starly, B., and Nam, J. Computeraided tissue engineering: overview, scope and challenges. Biotechnol Appl Biochem 39, 29, 2004.

43. Li, J., Regli, W.C., and Sun, W. An approach to integrating shape and biomedical attributes in vascular models. CAD Comput Aided Des 39, 598, 2007.

44. Khalil, S., Nam, J., and Sun, W. Multi-nozzle deposition for construction of 3D biopolymer tissue scaffolds. Rapid Prototyping J 11, 9, 2005.

45. Wenger, A., Stahl, A., Weber, H., Finkenzeller, G., Augustin, H.G., Stark, G.B., and Kneser, U. Modulation of in vitro angiogenesis in a three-dimensional spheroidal coculture model for bone tissue engineering. Tissue Eng 10, 1536, 2004.

46. Wenger, A., Kowalewski, N., Stahl, A., Mehlhorn, A.T., Schmal, H., Stark, G.B., and Finkenzeller, G. Development and characterization of a spheroidal coculture model of endothelial cells and fibroblasts for improving angiogenesis in tissue engineering. Cells Tissues Organs 181, 80, 2005.

47. Borges, J., Mueller, M.C., Padron, N.T., Tegtmeier, F., Lang, E.M., and Stark, G.B. Engineered adipose tissue supplied by functional microvessels. Tissue Eng 9, 1263, 2003.

48. Finkenzeller, G., Torio-Padron, N., Momeni, A., Mehlhorn, A.T., and Stark, G.B. In vitro angiogenesis properties of endothelial progenitor cells: a promising tool for vascularization of ex vivo engineered tissues. Tissue Eng 13, 1413, 2007.

49. Kunz-Schughart, L.A., Schroeder, J.A., Wondrak, M., van Rey, F., Lehle, K., Hofstaedter, F., and Wheatley, D.N. Potential of fibroblasts to regulate the formation of threedimensional vessel-like structures from endothelial cells in vitro. Am J Physiol Cell Physiol 290, C1385, 2006.

50. Rouwkema, J., de Boer, J., and Van Blitterswijk, C.A. Endothelial cells assemble into a 3-dimensional prevascular network in a bone tissue engineering construct. Tissue Eng 12, 2685, 2006.

51. Black, A.F., Berthod, F., L'Heureux, N., Germain, L., and Auger, F.A. In vitro reconstruction of a human capillarylike network in a tissue-engineered skin equivalent. FASEB J 12, 1331, 1998.

52. Levenberg, S., Rouwkema, J., Macdonald, M., Garfein, E.S., Kohane, D.S., Darland, D.C., Marini, R., Van Blitterswijk, C.A., Mulligan, R.C., D'Amore, P.A., and Langer, R. Engineering vascularized skeletal muscle tissue. Nat Biotechnol 23, 879, 2005.

53. Unger, R.E., Sartoris, A., Peters, K., Motta, A., Migliaresi, C., Kunkel, M., Bulnheim, U., Rychly, J., and James
Kirkpatrick, C. Tissue-like self-assembly in cocultures of endothelial cells and osteoblasts and the formation of microcapillary-like structures on three-dimensional porous biomaterials. Biomaterials 28, 3965, 2007.

54. Fraser, S.T., Ogawa, M., Nishikawa, S., and Nishikawa, S. Embryonic stem cell differentiation as a model to study hematopoietic and endothelial cell development. Methods Mol Biol 185, 71, 2002.

55. Newman, P.J. The biology of PECAM-1. J Clin Invest 100, S25, 1997.

56. Newman, P.J., and Newman, D.K. Signal transduction pathways mediated by PECAM-1: new roles for an old molecule in platelet and vascular cell biology. Arterioscler Thromb Vasc Biol 23, 953, 2003.

57. Kader, K.N., Akella, R., Ziats, N.P., Lakey, L.A., Harasaki, H., Ranieri, J.P., and Bellamkonda, R.V. eNOSoverexpressing endothelial cells inhibit platelet aggregation and smooth muscle cell proliferation in vitro. Tissue Eng 6, $241,2000$.

58. L'Heureux, N., Paquet, S., Labbe, R., Germain, L., and Auger, F.A. A completely biological tissue-engineered human blood vessel. FASEB J 12, 47, 1998.

59. Garlanda, C., and Dejana, E. Heterogeneity of endothelial cells: specific markers. Arterioscler Thromb Vasc Biol 17, 1193, 1997.

60. Augustin, H.G., Kozian, D.H., and Johnson, R.C. Differentiation of endothelial cells: analysis of the constitutive and activated endothelial cell phenotypes. BioEssays 16, 901, 1994.

61. Szmitko, P.E., Wang, C.H., Weisel, R.D., De Almeida, J.R., Anderson, T.J., and Verma, S. New markers of inflammation and endothelial cell activation part I. Circulation 108, 1917, 2003.

62. Owens, G.K. Regulation of differentiation of vascular smooth muscle cells. Physiol Rev 75, 487, 1995.

63. Owens, G.K., Kumar, M.S., and Wamhoff, B.R. Molecular regulation of vascular smooth muscle cell differentiation in development and disease. Physiol Rev 84, 767, 2004.

64. Kumar, M.S., and Owens, G.K. Combinatorial control of smooth muscle-specific gene expression. Arterioscler Thromb Vasc Biol 23, 737, 2003.

65. Feil, S., Hofmann, F., and Feil, R. SM22alpha modulates vascular smooth muscle cell phenotype during atherogenesis. Circ Res 94, 863, 2004.

66. Shanahan, C.M., and Weissberg, P.L. Smooth muscle cell heterogeneity: patterns of gene expression in vascular smooth muscle cells in vitro and in vivo. Arterioscler Thromb Vasc Biol 18, 333, 1998.

67. Sobue, K., Hayashi, K., and Nishida, W. Expressional regulation of smooth muscle cell-specific genes in association with phenotypic modulation. Mol Cell Biochem 190, 105, 1999.

68. Ford, M.C., Bertram, J.P., Hynes, S.R., Michaud, M., Li, Q., Young, M., Segal, S.S., Madri, J.A., and Lavik, E.B. A macroporous hydrogel for the coculture of neural progenitor and endothelial cells to form functional vascular networks in vivo. Proc Natl Acad Sci USA 103, 2512, 2006.

69. Griffith, C.K., Miller, C., Sainson, R.C., Calvert, J.W., Jeon, N.L., Hughes, C.C., and George, S.C. Diffusion limits of an in vitro thick prevascularized tissue. Tissue Eng 11, 257, 2005.

70. Geiger, F., Lorenz, H., Xu, W., Szalay, K., Kasten, P., Claes, L., Augat, P., and Richter, W. VEGF producing bone marrow stromal cells (BMSC) enhance vascularization and 
resorption of a natural coral bone substitute. Bone 41, 516, 2007.

71. Yang, J., Zhou, W., Zheng, W., Ma, Y., Lin, L., Tang, T., Liu, J., Yu, J., Zhou, X., and Hu, J. Effects of myocardial transplantation of marrow mesenchymal stem cells transfected with vascular endothelial growth factor for the improvement of heart function and angiogenesis after myocardial infarction. Cardiology 107, 17, 2007.

72. Egana, J.T., Fierro, F.A., Kruger, S., Bornhauser, M., Huss, R., Lavandero, S., and Machens, H.G. Use of human mesenchymal cells to improve vascularization in a mouse model for scaffold-based dermal regeneration. Tissue Eng Part A 15, 1191, 2008.

73. Cartmell, S.H., Porter, B.D., Garcia, A.J., and Guldberg, R.E. Effects of medium perfusion rate on cell-seeded threedimensional bone constructs in vitro. Tissue Eng 9, 1197, 2003.

74. Sanford, G.L., Ellerson, D., Melhado-Gardner, C., Sroufe, A.E., and Harris-Hooker, S. Three-dimensional growth of endothelial cells in the microgravity-based rotating wall vessel bioreactor. In Vitro Cell Dev Biol Anim 38, 493, 2002.

75. Dutt, K., Sanford, G., Harris-Hooker, S., Brako, L., Kumar, R., Sroufe, A., and Melhado, C. Three-dimensional model of angiogenesis: coculture of human retinal cells with bovine aortic endothelial cells in the NASA bioreactor. Tissue Eng 9, 893, 2003.

76. Obradovic, B., Carrier, R.L., Vunjak-Novakovic, G., and Freed, L.E. Gas exchange is essential for bioreactor cultivation of tissue engineered cartilage. Biotechnol Bioeng 63, 197, 1999.

77. Marolt, D., Augst, A., Freed, L.E., Vepari, C., Fajardo, R., Patel, N., Gray, M., Farley, M., Kaplan, D., and VunjakNovakovic, G. Bone and cartilage tissue constructs grown using human bone marrow stromal cells, silk scaffolds and rotating bioreactors. Biomaterials 27, 6138, 2006.

78. Augst, A., Marolt, D., Freed, L.E., Vepari, C., Meinel, L., Farley, M., Fajardo, R., Patel, N., Gray, M., Kaplan, D.L., and Vunjak-Novakovic, G. Effects of chondrogenic and osteogenic regulatory factors on composite constructs grown using human mesenchymal stem cells, silk scaffolds and bioreactors. J Royal Soc Interface 5, 929, 2008.

79. Bursac, N., Papadaki, M., White, J.A., Eisenberg, S.R., Vunjak-Novakovic, G., and Freed, L.E. Cultivation in rotating bioreactors promotes maintenance of cardiac myocyte electrophysiology and molecular properties. Tissue Eng 9, 1243, 2003.

80. Grayson, W.L., Bhumiratana, S., Cannizzaro, C., Chao, P.H., Lennon, D.P., Caplan, A.I., and Vunjak-Novakovic, G. Effects of initial seeding density and fluid perfusion rate on formation of tissue-engineered bone. Tissue Eng Part A 14, 1809, 2008.

81. Zhao, F., and Ma, T. Perfusion bioreactor system for human mesenchymal stem cell tissue engineering: dynamic cell seeding and construct development. Biotechnol Bioeng 91, 482, 2005.

82. Radisic, M., Yang, L., Boublik, J., Cohen, R.J., Langer, R., Freed, L.E., and Vunjak-Novakovic, G. Medium perfusion enables engineering of compact and contractile cardiac tissue. Am J Physiol Heart Circ Physiol 286, H507, 2004.

83. Niklason, L.E., Gao, J., Abbott, W.M., Hirschi, K.K., Houser, S., Marini, R., and Langer, R. Functional arteries grown in vitro. Science 284, 489, 1999.

84. Baguneid, M., Murray, D., Salacinski, H.J., Fuller, B., Hamilton, G., Walker, M., and Seifalian, A.M. Shear-stress preconditioning and tissue-engineering-based paradigms for generating arterial substitutes. Biotechnol Appl Biochem 39, 151, 2004.

85. Isenberg, B.C., Williams, C., and Tranquillo, R.T. Endothelialization and flow conditioning of fibrin-based media-equivalents. Ann Biomed Eng 34, 971, 2006.

86. Williams, C., and Wick, T.M. Perfusion bioreactor for small diameter tissue-engineered arteries. Tissue Eng 10, 930, 2004.

87. Williams, C., and Wick, T.M. Endothelial cell-smooth muscle cell co-culture in a perfusion bioreactor system. Ann Biomed Eng 33, 920, 2005.

88. Kofidis, T., Lenz, A., Boublik, J., Akhyari, P., Wachsmann, B., Mueller-Stahl, K., Hofmann, M., and Haverich, A. Pulsatile perfusion and cardiomyocyte viability in a solid three-dimensional matrix. Biomaterials 24, 5009, 2003.

89. Borenstein, J.T., Terai, H., King, K.R., Weinberg, E.J., Kaazempur-Mofrad, M.R., and Vacanti, J.P. Microfabrication technology for vascularized tissue engineering. Biomed Microdevices 4, 167, 2002.

90. Therriault, D., White, S.R., and Lewis, J.A. Chaotic mixing in three-dimensional microvascular networks fabricated by direct-write assembly. Nat Mater 2, 265, 2003.

91. Carraro, A., Hsu, W.M., Kulig, K.M., Cheung, W.S., Miller, M.L., Weinberg, E.J., Swart, E.F., Kaazempur-Mofrad, M., Borenstein, J.T., Vacanti, J.P., and Neville, C. In vitro analysis of a hepatic device with intrinsic microvascular-based channels. Biomed Microdevices 10, 795, 2008.

92. Lim, D., Kamotani, Y., Cho, B., Mazumder, J., and Takayama, S. Fabrication of microfluidic mixers and artificial vasculatures using a high-brightness diode-pumped Nd:YAG laser direct write method. Lab Chip 3, 318, 2003.

93. Vollmer, A.P., Probstein, R.F., Gilbert, R., and Thorsen, T. Development of an integrated microfluidic platform for dynamic oxygen sensing and delivery in a flowing medium. Lab Chip 5, 1059, 2005.

94. Fidkowski, C., Kaazempur-Mofrad, M.R., Borenstein, J., Vacanti, J.P., Langer, R., and Wang, Y. Endothelialized microvasculature based on a biodegradable elastomer. Tissue Eng 11, 302, 2005.

95. Bettinger, C.J., Weinberg, E.J., Kulig, K.M., Vacanti, J.P., Wang, Y.D., Borenstein, J.T., and Langer, R. Threedimensional microfluidic tissue-engineering scaffolds using a flexible biodegradable polymer. Adv Mater 18, 165, 2006.

96. Bettinger, C.J., Cyr, K.M., Matsumoto, A., Langer, R., Borenstein, J.T., and Kaplan, D.L. Silk fibroin microfluidic devices. Adv Mater 19, 2847, 2007.

97. Altman, G.H., Diaz, F., Jakuba, C., Calabro, T., Horan, R.L., Chen, J., Lu, H., Richmond, J., and Kaplan, D.L. Silk-based biomaterials. Biomaterials 24, 401, 2003.

98. Choi, N.W., Cabodi, M., Held, B., Gleghorn, J.P., Bonassar, L.J., and Stroock, A.D. Microfluidic scaffolds for tissue engineering. Nat Mater 6, 908, 2007.

99. Tang, M.D., Golden, A.P., and Tien, J. Fabrication of collagen gels that contain patterned, micrometer-scale cavities. Adv Mater 16, 1345, 2004.

100. Golden, A.P., and Tien, J. Fabrication of microfluidic hydrogels using molded gelatin as a sacrificial element. Lab Chip 7, 720, 2007.

101. Kelm, J.M., Djonov, V., Ittner, L.M., Fluri, D., Born, W., Hoerstrup, S.P., and Fussenegger, M. Design of customshaped vascularized tissues using microtissue spheroids as minimal building units. Tissue Eng 12, 2151, 2006. 
102. McGuigan, A.P., and Sefton, M.V. Vascularized organoid engineered by modular assembly enables blood perfusion. Proc Natl Acad Sci USA 103, 11461, 2006.

103. Leung, B.M., and Sefton, M.V. A modular tissue engineering construct containing smooth muscle cells and endothelial cells. Ann Biomed Eng 35, 2039, 2007.

104. McGuigan, A.P., and Sefton, M.V. The thrombogenicity of human umbilical vein endothelial cell seeded collagen modules. Biomaterials 29, 2453, 2008.

105. Chrobak, K.M., Potter, D.R., and Tien, J. Formation of perfused, functional microvascular tubes in vitro. Microvasc Res 71, 185, 2006.

106. Neumann, T., Nicholson, B.S., and Sanders, J.E. Tissue engineering of perfused microvessels. Microvasc Res 66, 59, 2003.

107. Lovett, M., Cannizzaro, C., Daheron, L., Messmer, B., Vunjak-Novakovic, G., and Kaplan, D.L. Silk fibroin microtubes for blood vessel engineering. Biomaterials 28, 5271, 2007.

108. Sekine, H., Shimizu, T., Yang, J., Kobayashi, E., and Okano, T. Pulsatile myocardial tubes fabricated with cell sheet engineering. Circulation 114, I87, 2006.

109. Yang, J., Yamato, M., Shimizu, T., Sekine, H., Ohashi, K., Kanzaki, M., Ohki, T., Nishida, K., and Okano, T. Reconstruction of functional tissues with cell sheet engineering. Biomaterials 28, 5033, 2007.

110. Shimizu, T., Sekine, H., Yang, J., Isoi, Y., Yamato, M., Kikuchi, A., Kobayashi, E., and Okano, T. Polysurgery of cell sheet grafts overcomes diffusion limits to produce thick, vascularized myocardial tissues. FASEB J 20, 708, 2006.

111. Lokmic, Z., Stillaert, F., Morrison, W.A., Thompson, E.W., and Mitchell, G.M. An arteriovenous loop in a protected space generates a permanent, highly vascular, tissueengineered construct. FASEB J 21, 511, 2007.

112. Mian, R., Morrison, W.A., Hurley, J.V., Penington, A.J., Romeo, R., Tanaka, Y., and Knight, K.R. Formation of new tissue from an arteriovenous loop in the absence of added extracellular matrix. Tissue Eng 6, 595, 2000.

113. Cassell, O.C.S., Morrison, W.A., Messina, A., Penington, A.J., Thompson, E.W., Stevens, G.W., Perera, J.M., Kleinman, H.K., Hurley, J.V., Romeo, R., and Knight, K.R. The influence of extracellular matrix on the generation of vascularized, engineered, transplantable tissue. Annals of the New York Academy of Sciences, 944, 429, 2001.

114. Manasseri, B., Cuccia, G., Moimas, S., D'Alcontres, F.S., Polito, F., Bitto, A., Altavilla, D., Squadrito, F., Geuna, S., Pattarini, L., Zentilin, L., Collesi, C., Puligadda, U., Giacca, M., and Colonna, M.R. Microsurgical arterovenous loops and biological templates: a novel in vivo chamber for tissue engineering. Microsurgery 27, 623, 2007.

115. Morritt, A.N., Bortolotto, S.K., Dilley, R.J., Han, X., Kompa, A.R., McCombe, D., Wright, C.E., Itescu, S., Angus, J.A., and Morrison, W.A. Cardiac tissue engineering in an in vivo vascularized chamber. Circulation 115, 353, 2007.

116. Kneser, U., Polykandriotis, E., Ohnolz, J., Heidner, K., Grabinger, L., Euler, S., Amann, K.U., Hess, A., Brune, K., Greil, P., Stürzl, M., and Horch, R.E. Engineering of vascularized transplantable bone tissues: induction of axial vascularization in an osteoconductive matrix using an arteriovenous loop. Tissue Eng 12, 1721, 2006.

117. Bach, A.D., Arkudas, A., Tjiawi, J., Polykandriotis, E., Kneser, U., Horch, R.E., and Beier, J.P. A new approach to tissue engineering of vascularized skeletal muscle. J Cell Mol Med 10, 716, 2006.

118. Beier, J.P., Horch, R.E., Arkudas, A., Polykandriotis, E., Bleiziffer, O., Adamek, E., Hess, A., and Kneser, U. De novo generation of axially vascularized tissue in a large animal model. Microsurgery 29, 42, 2009.

119. Laschke, M.W., Harder, Y., Amon, M., Martin, I., Farhadi, J., Ring, A., Torio-Padron, N., Schramm, R., Rücker, M., Junker, D., Häufel, J.M., Carvalho, C., Heberer, M., Germann, G., Vollmar, B., and Menger, M.D. Angiogenesis in tissue engineering: breathing life into constructed tissue substitutes. Tissue Eng 12, 2093, 2006.

120. Hellums, J.D., Nair, P.K., Huang, N.S., and Ohshima, N. Simulation of intraluminal gas transport processes in the microcirculation. Ann Biomed Eng 24, 1, 1996.

121. Jain, R.K. Transport of molecules across tumor vasculature. Cancer Metastasis Rev 6, 559, 1987.

122. Eggleton, C.D., Vadapalli, A., Roy, T.K., and Popel, A.S. Calculations of intracapillary oxygen tension distributions in muscle. Math Biosci 167, 123, 2000.

123. Griffith, L.G., and Swartz, M.A. Capturing complex 3D tissue physiology in vitro. Nat Rev Mol Cell Biol 7, 211, 2006.

124. Jain, R.K. Transport of molecules in the tumor interstitium: a review. Cancer Res 47, 3039, 1987.

125. Davis, B.H., Schroeder, T., Yarmolenko, P.S., Guilak, F., Dewhirst, M.W., and Taylor, D.A. An in vitro system to evaluate the effects of Ischemia on survival of cells used for cell therapy. Ann Biomed Eng 35, 1414, 2007.

126. Berkovitz, G.D., Fujimoto, M., Brown, T.R., Brodie, A.M., and Migeon, C.J. Aromatase activity in cultured human genital skin fibroblasts. J Clin Endocrinol Metab 59, 665, 1984.

127. Radisic, M., Deen, W., Langer, R., and Vunjak-Novakovic, G. Mathematical model of oxygen distribution in engineered cardiac tissue with parallel channel array perfused with culture medium containing oxygen carriers. Am J Physiol Heart Circ Physiol 288, H1278, 2005.

128. Truskey, G.A., Yuan, F., and Katz, D.F. Transport Phenomena in Biological Systems. Upper Saddle River, NJ: Pearson Prentice Hall, 2004.

129. Chary, S.R., and Jain, R.K. Direct measurement of interstitial convection and diffusion of albumin in normal and neoplastic tissues by fluorescence photobleaching. Proc Natl Acad Sci USA 86, 5385, 1989.

130. Zhao, F., Pathi, P., Grayson, W., Xing, Q., Locke, B.R., and $\mathrm{Ma}, \mathrm{T}$. Effects of oxygen transport on 3-D human mesenchymal stem cell metabolic activity in perfusion and static cultures: experiments and mathematical model. Biotechnol Prog 21, 1269, 2005.

131. Cochran, D.M., Fukumura, D., Ancukiewicz, M., Carmeliet, P., and Jain, R.K. Evolution of oxygen and glucose concentration profiles in a tissue-mimetic culture system of embryonic stem cells. Ann Biomed Eng 34, 1247, 2006.

132. Kellner, K., Liebsch, G., Klimant, I., Wolfbeis, O.S., Blunk, T., Schulz, M.B., and Gopferich, A. Determination of oxygen gradients in engineered tissue using a fluorescent sensor. Biotechnol Bioeng 80, 73, 2002.

133. Revsbech, N.P., and Ward, D.M. Oxygen microelectrode that is insensitive to medium chemical composition: use in an acid microbial mat dominated by cyanidium caldarium. Appl Environ Microbiol 45, 755, 1983.

134. Malda, J., Rouwkema, J., Martens, D.E., Le Comte, E.P., Kooy, F.K., Tramper, J., van Blitterswijk, C.A., and Riesle, J. 
Oxygen gradients in tissue-engineered PEGT/PBT cartilaginous constructs: measurement and modeling. Biotechnol Bioeng 86, 9, 2004.

135. Krihak, M.K., and Shahriari, M.R. Highly sensitive, all solid state fibre optic oxygen sensor based on the sol-gel coating technique. Electron Lett 32, 240, 1996.

136. Fink, T., Abildtrup, L., Fogd, K., Abdallah, B.M., Kassem, M., Ebbesen, P., and Zachar, V. Induction of adipocyte-like phenotype in human mesenchymal stem cells by hypoxia. Stem Cells 22, 1346, 2004.

137. Vanderkooi, J.M., Maniara, G., Green, T.J., and Wilson, D.F. An optical method for measurement of dioxygen concentration based upon quenching of phosphorescence. J Biol Chem 262, 5476, 1987.

138. Filho, I.P.T., and Intaglietta, M. Microvessel PO2 measurements by phosphorescence decay method. Am J Physiol Heart Circ Physiol 265, H1434, 1993.

139. Guaccio, A., Borselli, C., Oliviero, O., and Netti, P.A. Oxygen consumption of chondrocytes in agarose and collagen gels: a comparative analysis. Biomaterials 29, 1484, 2008.

140. Vinogradov, S.A., Lo, L.W., Jenkins, W.T., Evans, S.M., Koch, C., and Wilson, D.F. Noninvasive imaging of the distribution in oxygen in tissue in vivo using near-infrared phosphors. Biophys J 70, 1609, 1996.

141. Lo, L.W., Koch, C.J., and Wilson, D.F. Calibration of oxygendependent quenching of the phosphorescence of Pd- meso-tetra (4-carboxyphenyl) porphine: a phosphor with general application for measuring oxygen concentration in biological systems. Anal Biochem 236, 153, 1996.

142. Wilson, D.F., Lee, W.M.F., Makonnen, S., Finikova, O., Apreleva, S., and Vinogradov, S.A. Oxygen pressures in the interstitial space and their relationship to those in the blood plasma in resting skeletal muscle. J Appl Physiol 101, 1648, 2006.

143. Helmlinger, G., Yuan, F., Dellian, M., and Jain, R.K. Interstitial $\mathrm{pH}$ and $\mathrm{pO} 2$ gradients in solid tumors in vivo: highresolution measurements reveal a lack of correlation. Nat Med 3, 177, 1997.

Address correspondence to: David L. Kaplan, Ph.D. Department of Biomedical Engineering Tufts University 4 Colby St. Medford, MA 02155

E-mail: david.kaplan@tufts.edu

Received: February 6, 2009 Accepted: June 4, 2009 Online Publication Date: July 7, 2009 